\title{
The Combination of Building Greenery and Photovoltaic Energy Production-A Discussion of Challenges and Opportunities in Design
}

\author{
Irene Zluwa *(D) and Ulrike Pitha $\mathbb{D}$
}

Citation: Zluwa, I.; Pitha, U. The Combination of Building Greenery and Photovoltaic Energy Production-A Discussion of Challenges and Opportunities in Design. Sustainability 2021, 13, 1537. https://doi.org/10.3390/su13031537

Academic Editor: Francesco Nocera Received: 20 December 2020

Accepted: 22 January 2021

Published: 1 February 2021

Publisher's Note: MDPI stays neutral with regard to jurisdictional claims in published maps and institutional affiliations.

Copyright: (c) 2021 by the authors. Licensee MDPI, Basel, Switzerland. This article is an open access article distributed under the terms and conditions of the Creative Commons Attribution (CC BY) license (https:// creativecommons.org/licenses/by/ $4.0 /)$.
Department of Civil Engineering and Natural Hazards, Institute of Soil Bioengineering and Landscape Construction, University of Natural Resources and Life Sciences, A-1190 Vienna, Austria; ulrike.pitha@boku.ac.at * Correspondence: irene.zluwa@boku.ac.at

\begin{abstract}
In the case of building surfaces, the installation of green roofs or green facades can be used to reduce the temperature of the environment and the building. In addition, introducing photovoltaic energy production will help to reduce $\mathrm{CO}_{2}$ emissions. Both approaches (building greenery and photovoltaic energy production) compete, as both of them are located on the exterior of buildings. This paper aims to give an overview of solutions for the combination of building greenery (BG) systems and photovoltaic (PV) panels. Planning principles for different applications are outlined in a guideline for planning a sustainable surface on contemporary buildings. A comprehensive literature review was done. Identified solutions of combinations were systematically analysed and discussed in comparison with additional relevant literature. The main findings of this paper were: (A) BG and PV systems with low sub-construction heights require shallow substrates/low growing plants, whereas in the case of the combination of (a semi)-intensive GR system, a distance of a minimum $60 \mathrm{~cm}$ between the substrate surface and lower panel edge is recommended; (B) The cooling effect of the greenery depends on the distance between the PV and the air velocity; (C) if the substrate is dry, there is no evapotranspiration and therefore no cooling effect; (D) A spectrum of different PV systems, sub-constructions, and plants for the combination of BG and PV is necessary and suitable for different applications shown within the publication.
\end{abstract}

Keywords: green roof; vertical green; solar energy; green energy generation; PV rooftop garden; photovoltaic-green roof; PV-green roof; green roof; vertical green; photovoltaics

\section{Introduction}

Cities are being faced more frequently with an "urban heat island" (UHI) effect caused by sealed surfaces and densely built-up areas. Strategies against UHI effects are de-sealing of surfaces (for better water retention and active cooling via transpiration), usage of reflective surfaces (to reduce heat-storage in materials) and reduction of $\mathrm{CO}_{2}$ emissions [1,2].

In the case of building surfaces, the installation of building greenery (BG or BG systems), also known as a green roof (GR) or vertical green (VG), can be a tool to reduce the temperature of the environment and the building. Building greenery can add an extra layer of insulation to a building, and create shade made by the leaves of plants (of course, depending on type of system and insulation of the building). This leads to less heat storage within the building materials and encourages cooling, due to the evapotranspiration in the building greenery systems [3,4].

On the other hand, the reduction of greenhouse gasses was appointed in the Paris Agreement [5], with the intention to limit global warming. Thereby the reduction of $\mathrm{CO}_{2}$ emissions is an important aspect, which can be accomplished by forcing renewable energy production (for example via photovoltaic). 
The crucial point is that both approaches (building greenery and photovoltaic energy production), are in competition, as both are located on the exterior of buildings (roof or façade). With the goal to design solutions with a combined use of these technologies for building exteriors, different projects have been developed in which various combinations of photovoltaic (PV) panels and BG systems were investigated. Despite there being many advantages found when studying a combination of BG systems and PV energy production as reported in various publications (see Section 3.3), the problem of shade on the PV panels caused by plants and more difficult maintenance of the green roof is hardly addressed in publications [6,7].

The aim of this paper is to give an overview of different solutions for the combination of building greenery systems and PV panels. The focus of the implemented example analysis is based on design combinations, pointing out the interaction of planting layers, sub construction and PV, maintenance and the PV performance. Additional information about the described advantages and disadvantages are documented and summarized. Challenges and opportunities are identified to derive, in a further step, planning principles for the combination of building greenery and photovoltaic energy production as sustainable exteriors of contemporary buildings.

\section{Method}

The derivation of results in the present paper was done in 4 steps:

\subsection{Step 1: Literature Review}

Literature reviews and studies about the interaction of building greening systems and photovoltaic energy production were collected and studied. Relevant terms are defined and explained in the background section of the paper (Section 3).

\subsection{Step 2: Selection of Discussed Objects}

Out of the reviewed publications, those referring to practical tests on real PV and BG implementations on a larger scale were chosen for the description of the examples, to give a broad overview of various system types regarding (sub-) construction (as shown in Figure 1), types of plants, and heights. Moreover, scientifically analysed and reported data was a criterium for the selection of the 12 examples. Small (model size) studies and studies with only a short investigation period were excluded.

Technical solutions and constructive details of the chosen projects were described, and (if available) information about energy output was collected, as well as information about used plants and their development.

The following analysis criteria regarding each project were listed systematically in Section 4: Type of GR/VG, PV-type and mounting; plant development influenced by the $\mathrm{PV}$; and maintenance and (estimated) energy output/thermal behaviour. The distance of the green roof's surface to the lower side of the panel leads to the order of the listed examples, because the sub-construction height seems like a critical factor for the interaction of PV and BG, which is shown in the findings of multiple analysed projects [8-10].

\subsection{Step 3: Matrix of Opportunities and Challenges}

In the results section (Section 5), the different designs and combinations of BG and PV are analysed, and problems and synergies are outlined. The analysed projects are presented in a matrix in the same order as in Section 4 (4.1, 4.2, 4.3 etc.) If there are different design types in a project described, the variants are labelled with " $a$ ", " $b$ " and "c".

The matrix of opportunities and challenges informs about: the distance of the substrate (surface) to the (lower) PV panel (side), PV-inclination, type of green roof (GR) and vertical green (VG), synergy of greening system and PV, standard (sub-construction) PV system, maintenance, irrigation, advantages / disadvantages for plants and improvement on energy production/lower air (or PV-panel) temperatures. 


\subsection{Step 4: Summarizing of Main Findings and Discussion}

Finally, the findings are summarized and discussed with additional literature. Planning principles were deduced from the analysis outcomes. In the end, an outlook to further research demand will be given.

\section{Background and Technical Terms}

This section intends to inform the reader about the technical background of building greenery and photovoltaic energy production technologies. The terms used within this publication will be explained, as well as the advantages and possibilities of the specific technologies will be shown:

\subsection{Building Greenery (BG)}

Implementing green infrastructure (GI) in cities is an important strategy to help inhabitants stay healthy [11]. GI also offers many other benefits such as noise reduction, stormwater retention and dust-particle filtering. Green infrastructures help to increase biodiversity by providing habitats for plants and animals as well as improving the urban microclimate [12,13]. Building greenery (the implementation of green roofs and green facades on buildings) is one type of green infrastructure. The higher the Urban Heat Island effect is, the more sealed the surfaces in the areas are. Depending on the density of buildings and the possibilities for applying other green infrastructure, there might be GI solutions with a higher impact for cooling (e.g., a large park with old trees and water reservoirs) [2]. However, building greenery is a suitable method for enhancing positive microclimatic effects. Speaking of a limited area and the wish for renewable energy production, there is a need for combined systems to exploit surfaces efficiently.

For further understanding, the technical background and the different categories of green roofs and green facades are presented below.

\subsubsection{Green Roofs (GR)}

"A green roof is a layer of vegetation planted over a waterproofing system that is installed on top of a flat or slightly-sloped roof" [14]. Form the bottom-up the construction of a green roof consists of a waterproof and root-repellent sealing, a storage and drainage layer, a filter membrane, a technical soil layer (mineral aggregates with few organic material) and plants $[15,16]$. Within this publication, this construction will be named the "vegetation layer".

Typically, there are three main categories described [17]:

- Extensive green roofs have a low construction height below $15 \mathrm{~cm}$. They only need to be maintained once a year and do not require additional watering. Typical plant communities are sedum, sedum-herb communities, or sedum-herb-grass communities. Furthermore, small shrubs can be planted. This type of roof greening is not designed for regular access of people.

- Semi-intensive green roofs are constructed with a height between 16 and $20 \mathrm{~cm}$. It is also possible to incorporate higher plants such as grasses, shrubs and perennials. Limited watering and maintenance are required. It is possible for people to access.

- Intensive green roofs and roof gardens need high maintenance and regular watering. All types of plants, even trees or edible plants, can be included. The design can be remarkably diverse, according to its purpose, from representative green, to recreation or even for urban gardening, or moreover urban farming.

Besides choosing suitable plant communities, other factors such as load weight, composition of the technical soil and efficient drainage must be considered in the planning and maintenance process of a green roof [18].

In addition to the above-mentioned benefits of GI, a GR can improve a building's thermal behaviour by giving extra insulation. Furthermore, it offers cooling effects due to evapotranspiration when the substrate is wet. Construction height and composition of different layers influence the thermal processes within the building [3] and the energy 
consumption of a building [19-21], as various authors proved in their publications for different regions. It is hard to compare the results of the different studies because green roofs are "living dynamic systems" [3], which respond differently in climatic framework conditions (summer/winter/climate zone, etc.) An example is given for an industrial building without insulation in Vienna. The GR variant with $12 \mathrm{~cm}$ substrate showed an $\mathrm{u}$-value of $0.944 \mathrm{~W} / \mathrm{m}^{2} . \mathrm{K}$, while the $30 \mathrm{~cm}$ thick green roof showed much better insulation values of $0.299 \mathrm{~W} / \mathrm{m}^{2}$.K. Furthermore, the insulation effects were different during winter and summer, mostly depending on the moisture in the substrate. Another study in Vienna calculated that if every flat roof was a green roof and all sloped roofs were covered in highly reflective material, the number of heat days could be reduced by $29 \%$ in the inner city centre and by $20 \%$ in less-dense areas of Vienna [1].

\subsubsection{Vertical Green (VG)}

In contrast to the clear definitions of GR, the terms used within publications addressing vertical green are not this clear. Different publications refer to various systematics and terminologies [22-24]. In most of the publications, the classification is divided into:

- Green facades, which are VG systems with climbing plants, either planted directly into the ground or in planters placed on the ground. The plants can climb directly on the wall, or on a secondary support system $[23,24]$.

- Living walls refer to vegetation in systems applied directly on the façade [23,24]. Within the last few years, there can be found a broad range of living wall systems on the market, differing in material and design (in turn leading to different water demands and ecological footprints of such systems [25]). The vegetation consists of annuals, perennials, grasses and small shrubs.

In living wall systems and planters with climbers, irrigation is a must [24,26].

Like GR, VG also improves the thermal behaviour of a building by creating shade on the façade, and therefore reduces building surface temperature. VG also reduces the heat flux throughout building surfaces [23] (especially when applied to buildings without insulation [4]. On insulated buildings, the mounting can cause thermal bridges [27]).

\subsection{Photovoltaic (PV) Energy Production}

The conversion of light into electricity via semiconducting materials is called photovoltaics. Photovoltaic cells are able to convert sunlight directly into electricity. The cells consist commonly of silicon (Si) and compounds of cadmium sulphite (CdS), cuprous sulphite (Cu2S), and gallium arsenide (GaAs) [28].

Celadin and Filipek [29] describe three generations in the development of PV cells:

- Monocrystalline silicon cells were the first PV cells on the market. They have the highest efficiency, are durable and expensive. Their colour is black or deep blue. Polycrystalline silicon cells are less expensive, have lower efficiency, and there is a broader range of colours available.

- Transparent thin-film cells are less durable, less expensive and have lower efficiencies, but allow flexible installation, even on curved surfaces.

- In the third generation, there are many new inventions of various technologies. For example, a polymer-based system of dye-sensitized solar cells or Perovskite-Si tandem cells [29]. New designs of cells are cells with laser-cut holes for shading effects or transparent effects when installed in a certain distance to the eye [30].

Photovoltaic cells are combined within a PV panel. A PV panel can produce a specific amount of voltage when light enters the PV cells [28]. The panels can be produced opaque or (semi)-transparent [30]. Their installation can be fixed or mobile to track the sun. They can be mounted on the ground, on the roof or on the façade. Building-integrated PV systems (BIPV) are in some way connected directly to a building component [29].

PV panels are connected in series or a row to form a PV system. PV systems can be grid-connected or stand-alone systems [31]. 
According to Köhler et al. [32], the efficiency of PV systems depends on:

- type of photovoltaic cells (as mentioned above, each cell has a different capacity; this does not depend only on the type, but also on factors such as the difference in production within each cell of the same type);

- $\quad$ type of inverter (transforming direct current (DC) in alternating current (AC));

- inclination of module and system;

- $\quad$ shade and reflections from the surroundings (built or natural elements [29]);

- a fixed installation or tracking system that moves with the sun;

- local climate (air temperature, wind, radiation, direct influence of rain, as well as annual differences in climate factors);

- temperature of the cell (optimum around $20^{\circ} \mathrm{C}$ [29]) and therefore surface materials below the panel; and

- frequent maintenance of the whole system.

In addition to the generation of energy, PV panels protect the building from weather, provide shading from the sun, or work as an insulation layer [29]. Furthermore, if they are mounted to a building, no extra space on the ground for the PV system is required.

\subsection{Combination of Building Greenery and Photovoltaic Energy Production}

In consideration of the limed urban roof area, both technologies (BG and PV energy production) are often viewed as competitors [6], a combination of both technologies (BG and PV energy production) appears to be important when striving for a holistic design of contemporary buildings [33].

The advantages of a PV-green roof in comparison to a standard green roof can be summarized in the following points:

- Renewable energy production on the building is possible [34].

- Plant growth and further development of plants, as well as species richness, are enhanced due to the shading effect of the PV [35].

- $\quad$ Plants under the PV panels are protected from the cold in winter [34].

- Positive synergy between substrate/plants and PV panels is documented. A cooling effect occurs due to evapotranspiration. Moreover, there is an albedo effect of the plants, leading to increased energy efficiency (depending on plants, substrate and climatic conditions) [34].

- $\quad$ Reduced energy consumption for cooling buildings (depending on climate conditions and insulation of the building) [34].

- Improved utilization of the available roof space is possible [34].

- Potential for carbon sequestration is given (avoiding carbon production because of green energy production and carbon sequestration by soil/plant layer) [7].

- Potential for urban agriculture is given [7].

- PV panels work as a nurse object, helping plants to survive under harsh climate conditions of an extensive GR, because the soil moisture content is higher for a longer period under PV panels [7].

- $\quad$ GR substrates provide weight to secure PV panels to the roof. Therefore, no extra weight must be added [36,37].

Pfoser discusses technical solutions regarding the merging of BG and PV in her work $[38,39]$, in Figure 1 schematic drawings for potential combinations of PV and GR are shown: PV panels and GR can be side by side, PV panel can be on a shed roof with GR besides, PV panels can be on a GR with a sub-construction for the optimal inclination of the PV, PV panels and GR can be integrated in sun-tracking PV systems, PV panels can be orientated with an optimized inclination on a GR using a stand-alone sub-construction, PV panels can be orientated in an E-W direction on a GR, bifacial PV panels can be placed on a GR, PV panels can be installed on a pergola-like sub-construction on a GR. 


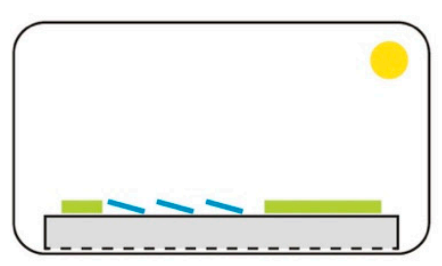

PV panels and GR side by side,

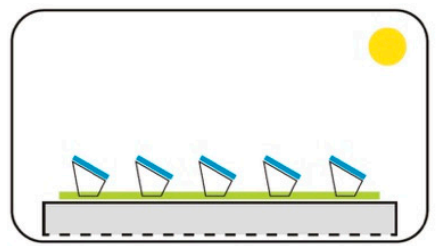

PV panels with optimized inclination with stand-alone sub-construction,

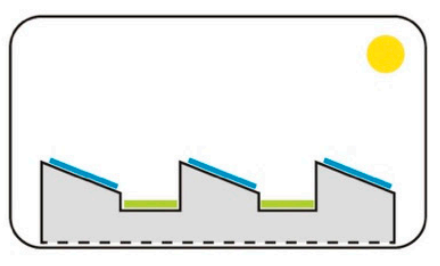

PV on a shed roof with GR besides,

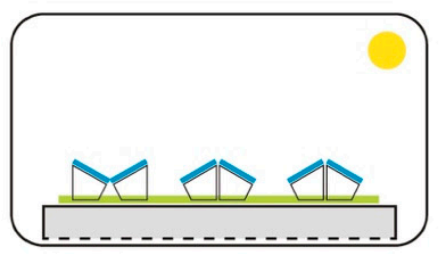

E-W oriented PV,

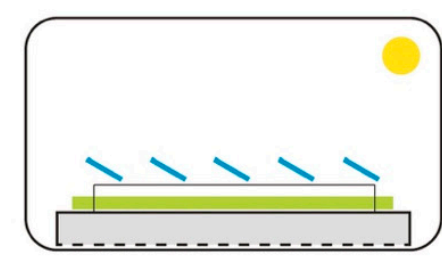

PV panels on a sub-construction for optimal inclination of the PV,

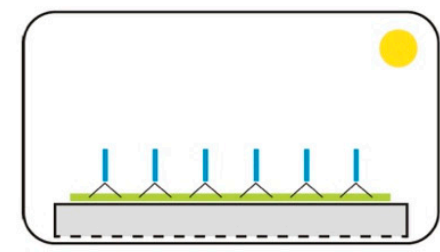

bifacial PV panels,

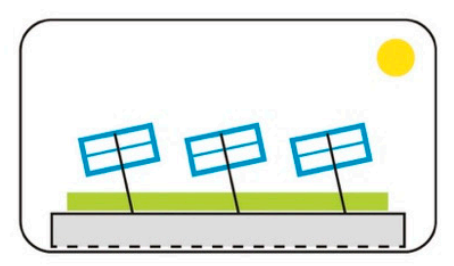

GR with sun tracking PV systems

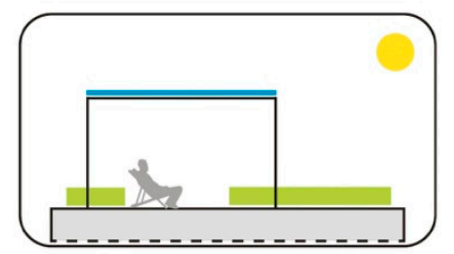

PV on a pergola-like sub construction

Figure 1. Schematic drawings for possible installations of PV panels on green roofs (modified according to Pfoser in [38]).

For the planning of combined GR-PV systems, the following principles are recommended [38]:

- Check for the possibility of funding;

- Calculate maintenance efforts;

- Obtain approvals;

- Calculate statics (wind load and load on the roof-construction);

- Investigate the shading of surrounding buildings, vegetation or installations;

- Allow accessibility to the roof for maintenance and transport of material;

- Secure water runoff (and water supply);

- Coordinate the different technical crews;

- Select the ideal combination of substrate height, plant community and sub-construction.

However, there is still a lack of knowledge regarding the final point of the abovenamed recommendations. The interaction of substrate, plant communities and water regime influenced by the PV panels have not yet been well investigated. Sub-construction designs still need to be improved to allow bigger substrate heights, avoid shade made by plants and reduce maintenance costs.

\section{Examples of Practical Approaches for the Combination of Building Greenery (BG) and Photovoltaics (PV)}

Twelve realized examples for different combinations of BG and PV will be presented in the following section. Collected information given in the papers is collected systematically:

- Type of GR/VG: This criterion defines the height and material of the vegetation layer of the green roof or the vertical greening system. Moreover, information about the selected plant species is given.

- PV-type and mounting: The sub-construction (material, distance from substrate surface to the lowest edge of the PV-panel and mounting) is described in this section. Inclination and orientation of the PV, as well as panel size and cell material, is given if available.

- Plant development influenced by PV: Information about plant growth, vitality, and flowering success of species or plants in total is collected here.

- Maintenance: Information about needed services for the PV system or cutting the vegetation and removing unwanted species is noted in this section. 
- (Estimated) energy output/thermal behaviour: Information about the harvested energy yield is collected. The measured temperature of surfaces (panel, different roof type etc.) that influences the performance of the PV module is listed.

\subsection{Test Facility 1 in Winterthur (Switzerland)}

In Winterthur, a large test facility was installed to investigate potential higher PV efficiency based on the cooling effects of green roofs. Two different PV systems, from ZINCO (Nürtingen, Germany) and HILTY (Schaan, Liechtenstein) were mounted on a green roof and on a gravel roof as reference (see Figures 2 and 3). A report was given in 2016 by Baumann et al. [40]

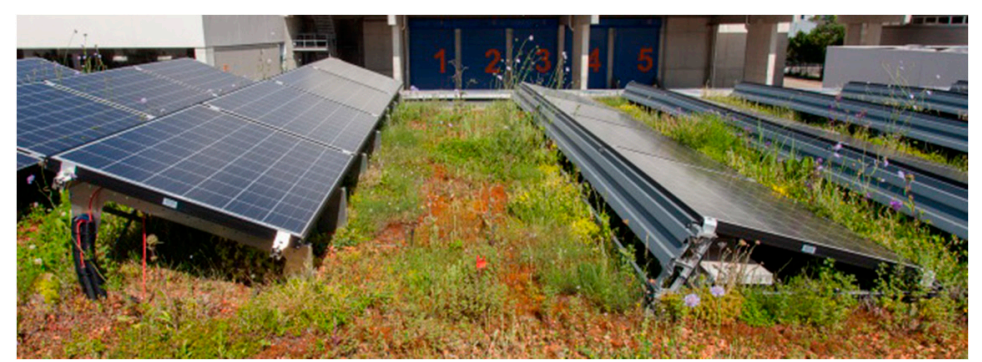

Figure 2. ZINCO (left) and HILTI (right side of the picture) system at the test facility in Winterthur (picture: Baumann et al. [40].

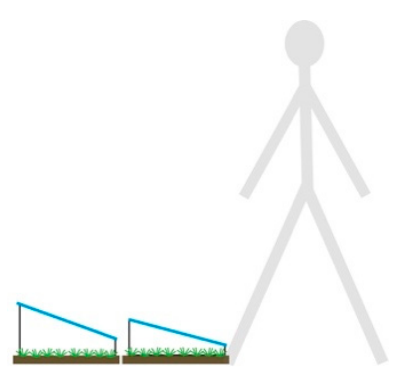

Figure 3. Schematic drawing of the PV GR systems at the test facility in Winterthur (sketch: Irene Zluwa).

Type of GR: 7-13 cm substrate was seeded with a sedum and herb-mixture consisting of Alyssum alyssoides, Campanula cochleariifolia, Campanula rotundifolia, Filago vulgaris, Globularia bisnagarica, Helianthemum nummularium, Hippocrepis comosa, Petrorhagia saxifraga, Pseudolysimachion spicatum, Sedum acre, Sedum album, Sedum rupestre, Sedum sexangulare, Teucrium botrys, Teucrium chamaedrys and Thymus pulegioides [41].

PV-types and mounting: The first system is a HILTI PV system for conventional flat roofs with an inclination of $15^{\circ}$. The panels simply lie on the roof and additional weight is added to secure them against wind loads. The second system was a ZINCO mounting system designed for a green roof with $20^{\circ}$ tilted PV panels, the weight of the substrate secures them against wind loads.

Plant development influenced by PV: No information was given in the paper.

Maintenance: It was not specifically mentioned in the paper if there were issues in which plants caused shade on the panels. However, it was clearly described that there is a need for optimised mounting systems for PV panels on GR to avoid expensive maintenance costs.

(Estimated) energy output/thermal behaviour: Over the analysed period (from 1 October 2014 to 31 May 2016), 99 MWh were generated from both systems. No significant cooling effect was reported (the air temperature was $0.4{ }^{\circ} \mathrm{C}$ lower at the PV panels on the green roof in comparison to the gravel roof). 


\subsection{Science Research and Teaching Center (SRTC) Building at Portland State University (PSU) in} Portland (USA, Oregon)

Ogaili [42] and Ogaili and Sailor [43] reported on a study of the "effect of vegetated roofs on the performance of photovoltaic panels in a combined system". They were investigating different roof types (green roof, black roof and white roof) and different panel heights. The test plots (see Figure 4) were situated at the Science Research and Teaching Center (SRTC) Building at Portland State University (PSU), Portland, Oregon, United States.

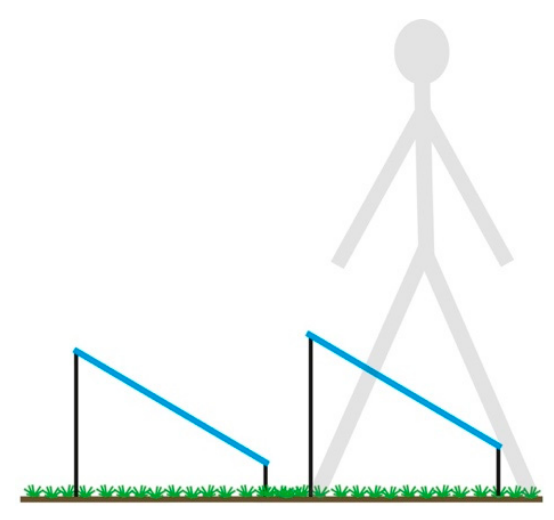

Figure 4. Schematic drawing of the experimental setup, Portland State University (PSU) (sketch: Irene Zluwa).

Type of GR: The GR is a single layer construction ( $6 \mathrm{~cm}$ substrate) planted with Dianthus sp. For the black and the white reference roofs, an ethylene propylene diene monomer (EPDM) film in both colours was used. Each test area has a size of 2.2 to $3 \mathrm{~m}$.

PV types and mounting: Panels ( 0.8 to $1.6 \mathrm{~m}$ ) were mounted on a metal sub-construction with a southern orientation and an inclination of $30^{\circ}$. Each panel has its own micro inverter with a power output of 210 Watts. Two different panel heights, measuring 12 and $18 \mathrm{~cm}$ distance between the substrate surface and the lower edge of the PV panel were investigated within the experiment.

Plant development influenced by PV: There was no information provided in the paper.

Maintenance: No maintenance was discussed in the paper, however, due to the short investigation period between July and September, it is suggested that no maintenance was required during that period.

(Estimated) energy output/thermal behaviour: The air temperature measured on the GR with PV panels was $1.4{ }^{\circ} \mathrm{C}$ cooler in the system with the larger distance of $18 \mathrm{~cm}$ between substrate and PV panels in comparison with the system with $12 \mathrm{~cm}$ distance between substrate and PV. It was assumed that this was due to a better airflow under the PV panels.

The albedo was measured for all three kinds of surface: The albedo of the GR was 0.28 , the black roof had 0.06 , and the white roof showed an albedo of 0.64 .

The panel temperature above GR was $2.5^{\circ} \mathrm{C}$ cooler than on the test site with PV panels on a black roof, which leads to an increase in energy production of $1.16 \%$ for the system with a distance of $16 \mathrm{~cm}$. The lower system (12 cm distance) was $1.8 \%$ cooler and generated $1 \%$ more energy.

In comparison to the test site with PV panels on a white roof, the air temperature at the GR with PV panels was $3{ }^{\circ} \mathrm{C}$ cooler in the $16 \mathrm{~cm}$ distance system and $1.5 \%$ cooler in the system with $12 \mathrm{~cm}$ distance between substrate surface and PV panels. However, the energy production of the GR with PV panels was only $0.75 \%$ and $0.68 \%$ higher, potentially due to the reflections from the white surface.

In the analysed publication, it was also mentioned that differences in air temperature between the black and white roof were caused by the measurement setup and given weather conditions during the experiment. 


\subsection{Examination Site at the University of Haifa in Haifa (Israel)}

Schindler et al. [44] presented a study on their PV and GR examination site at the University of Haifa in Israel. Three different roof designs were installed and examined: a green roof, a green roof with PV panels and PV panels on a bitumen roof (see Figure 5).

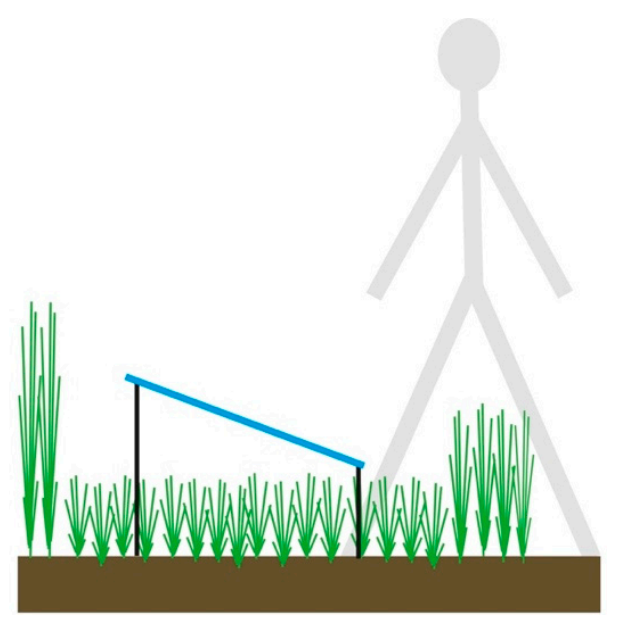

Figure 5. Schematic drawing of the examination site at the University of Haifa in Israel (sketch: Irene Zluwa).

Type of GR: The drainage layer consists of non-woven geotextile pillows filled with tuff, placed next to a drainage pipe. Above, a $20 \mathrm{~cm}$ high substrate layer $(70 \%$ perlite, $15 \%$ $0 / 8 \mathrm{~mm}$ tuff, and $15 \%$ compost) was built in. Sedum sediforme-cuttings and annual plant species were seeded (Cichorium pumilum, Ranunculus scandicinus, Hirschfeldia incana, Daucus broteri, Lavatera cretica, Stipa capensis, Ricotia lunaria, Chrysanthemum coronarium, Anthemis pseudocotula, Lomelosia prolifera, Agrostemma gracile, Capsella bursa-pastoris, Heliotropium europaeum, Echium judaeum, Chaetosciadium trichospermum, Lagurus ovatus, Trifolium purpureum, Trifolium palaestinum, Silene aegyptiaca and Papaver carmeli).

PV types and mounting: $250 \mathrm{~W}$ solar panels with the size of $1 \times 2 \mathrm{~m}$ were mounted on pavement stones. The inclination of the panels is descripted with an angel of $20^{\circ}$. The lower edge of the panel is $30 \mathrm{~cm}$ over the soil surface.

Plant development influenced by PV: The authors interpreted that direct shade throughout the day is not beneficial to most species. This statement was based on the conducted observation about a lower abundance of plants under PV panels. There was no difference in species richness between GR with PV and GR without PV. However, the flowering season (starting in the same week on both plots) yet lasted longer under the PV panels. Furthermore, the sedum sprouts were proven to grow larger under the PV panels. In the discussion, it is mentioned that in the second year of the study, the plant communities differed between roofs with and without PV panels.

Information about maintenance: Vegetation was trimmed to a height of $30 \mathrm{~cm}$ around the PV panels, $50 \mathrm{~cm}$ in front of the panels and $30 \mathrm{~cm}$ beside the panels. The remaining area of the plot was trimmed to $80 \mathrm{~cm}$ in the front and $60 \mathrm{~cm}$ in the back to avoid shading.

(Estimated) energy output/thermal behaviour: The temperature of the PV panels was generally the same on the GR and bitumen roof (but slightly warmer on bitumen in winter). There was no difference in energy production. The reason for this is suspected to be due to the dry substrate (the system was not irrigated). Therefore, plants and soil had no evapotranspiration to provide cooling effects.

Further information: Investigations on arthropod communities were included in the paper yet did not show truly clear results. However, the trend seemed to show a lower arthropod abundance on the GR with PV than on GR without PV.

Dust coverage on the PV panels was additionally recorded. The amount was the same for both plots (on a GR and conventional bitumen roof). 


\subsection{Test Facility 2 in Winterthur (Switzerland)}

Based on the findings of the project mentioned in 4.1, a further research project (started in 2016) is testing new types of bifacial cells and mounting systems [6] (see Figures 6 and 7).

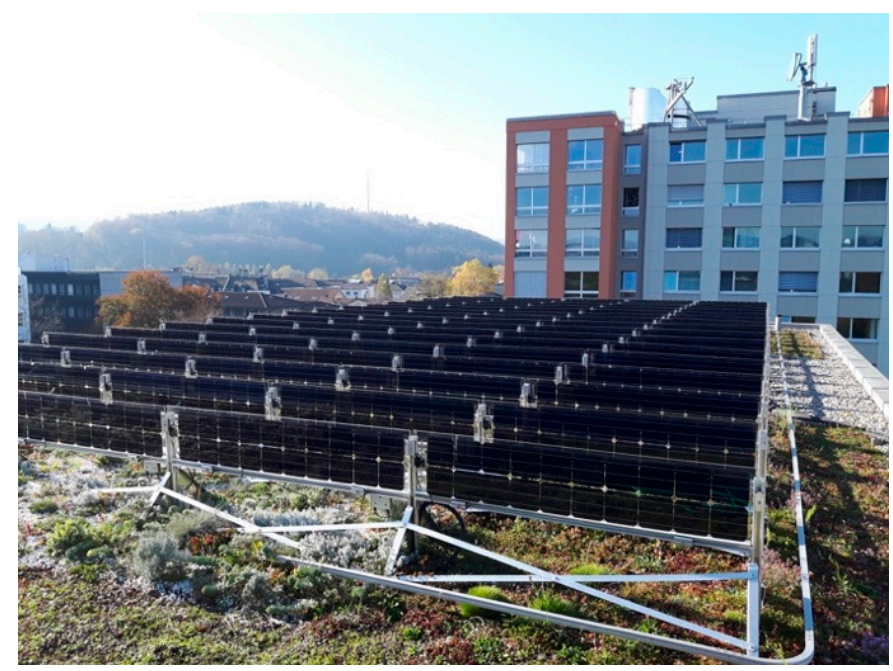

Figure 6. Photo of the bifacial PV system in Winterthur (Switzerland) (photo: M. Klenk).

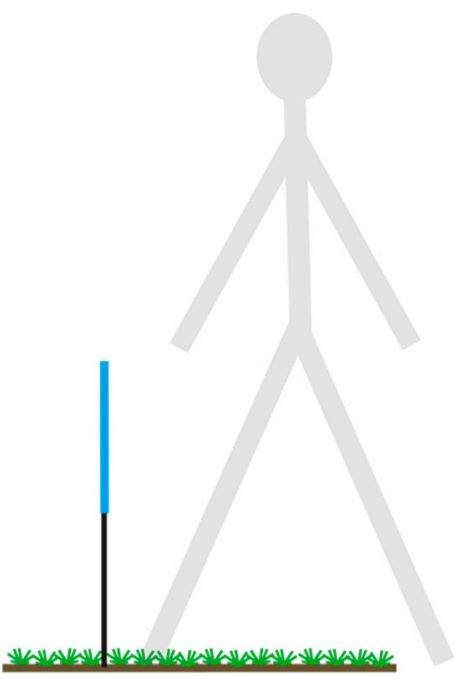

Figure 7. Schematic drawing of the bifacial PV system in Winterthur (sketch: Irene Zluwa).

Type of GR: Two different types of green roofs were installed: a standard green roof with regular substrates and plants and a "reflective" green roof with white gravel and silver-leaved plants (creating a higher albedo).

PV types and mounting: Custom-made vertical bifacial modules (glass-glass) are installed on a mounting system. The distance between the substrate of the green roof layer and the lower edge of the module amounts to $40 \mathrm{~cm}$ in order to avoid shading effects made by plants and the covering of PV panels by snow in winter. The panels are orientated towards an East-West direction. As a reference, a regular monocrystalline PV module with regular mounting was used. It was installed on a regular extensive GR with a southern direction.

Plant development influenced by PV: It is reported that the silver-leaved plants showed a higher resilience throughout dry periods.

Maintenance: Maintenance work is easily managed because the area between the PV module rows can be easily accessed. An idea of using robots for further maintenance is mentioned in the conclusion section of the paper. 
(Estimated) energy output/thermal behaviour: The albedo was higher on the variant with gravel and silvery leaved plants than on the standard green roof, and lead to an increased solar yield of about 16.6-17.1\%. Bifacial East-West orientated cells have their peaks in the morning and afternoon, the standard south-oriented module has its peak at noon. Another disadvantage of the bifacial modules is that a low ground cover ratio is needed to avoid mutual shading. Therefore (if maximum installed capacity in $\mathrm{kWp}$ per available roof area is the goal), the total yield for this type of installation is lower than for standard monofacial systems.

The PV system produced $9.09 \mathrm{kWp}$ nominal power from May to September; the South orientated monofacial variant (reference module): $603.2 \mathrm{kWh} / \mathrm{kWp}$, the East-West bifacial standard green roof $476.3 \mathrm{kWh} / \mathrm{kWp}$ and the high albedo green roof $557.9 \mathrm{kWh} / \mathrm{kWp}$.

\subsection{Testing Station "Öko-Prïfstand" of the TU Wien in Vienna (Austria)}

A research group of the Viennese Technical University built a testing station ("ÖkoPrüfstand") at the test area of the Research Centre of the Building for Physics and Sound Protection (see Figures 8 and 9). Korjenic and Perenanda-Moren discussed the effect of climbing plants behind semi-transparent PV panels within two publications $[45,46]$.

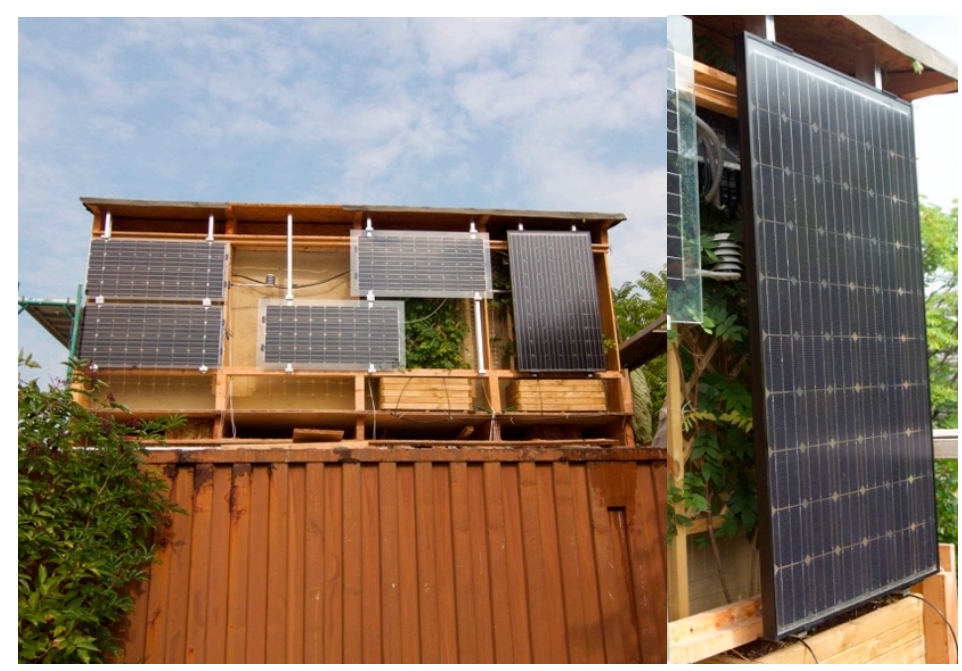

Figure 8. Photos of the Öko-Prüfstand at TU Wien, Austria (photos: TU Wien-Korjenic).
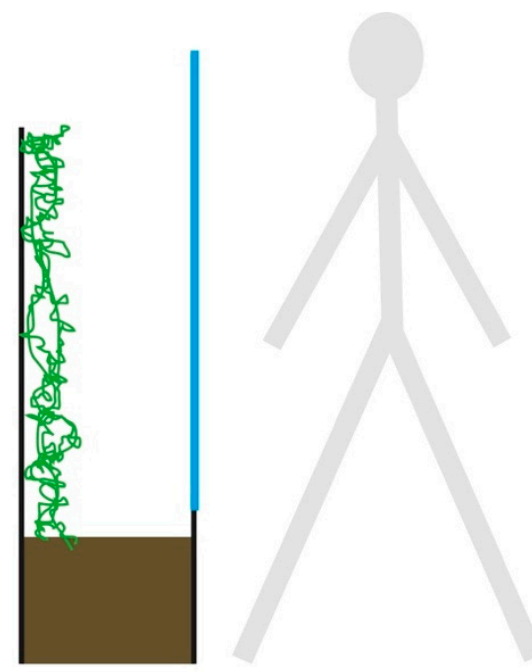

Figure 9. Schematic drawing of the Öko-Prüfstand at TU Wien (sketch: Irene Zluwa). 
Type of VG: Climbing plants (Wisteria sinensis, Campsis radicans, Lonicera henryi) on wooden trellis and galvanized steel frameworks were placed in planters (filled with green roof substrate).

PV types and mounting: SOLARWATT (Dresden, Germany) glass-glass modules with monocrystalline cells were placed in Eastern orientation with an inclination of $90^{\circ}$. The distance between the façade and the PV panel was $45 \mathrm{~cm}$. Variant 1 and 3 have semitransparent panels, Variant 4 was equipped with standard opaque panels (see Figure 8).

Plant development influenced by PV: The plants could develop behind the PV systems.

Maintenance: In summer, an irrigation system was used. In winter, the plants were watered manually.

(Estimated) energy output/thermal behaviour: Further development of plants (higher leaf density and plant size) results in lower module temperatures. The greenery reduces the PV operating temperature to $1-4{ }^{\circ} \mathrm{C}$ lower when the outdoor temperature is $20{ }^{\circ} \mathrm{C}$. The benefits were only positive for specific time intervals under extreme conditions (e.g., in summer at noon when it was hot outside, and the PV modules were also hot) [45]. The combination of greening and PV reduces building surface temperatures in summer (up to $30^{\circ} \mathrm{C}$ lower façade temperature on a hot summer day could be documented (average temperature of $21^{\circ} \mathrm{C}$ was measured over all the summer months) in comparison to the reference without PV and green). In winter, the cooling effect on the building surface temperature was limited to $3{ }^{\circ} \mathrm{C}$ on average when the air temperature was below $0{ }^{\circ} \mathrm{C}$ [46].

\subsection{System 1 on a School Building in Vienna (Austria)}

In the research project "GreenPlusSchool@Megalopolis: Efficient living walls and green roofs combined with photovoltaic - an optimal solution for energy efficiency and in view of ecology" [8] various greenery systems were investigated inside and outside of a school building located in Kandlgasse 39, 1070 Vienna, Austria. One focus of the project was on the development and testing of two different design approaches for the combination of PV panels and GR. The first design is a living wall combined with semi-transparent PV panels in front of the greenery. Two distances $(25 \mathrm{~cm}, 45 \mathrm{~cm})$ between the PV panels and the living wall were monitored, as well as a special mounting frame for the PV panels that should enhance the handling of plant maintenance, were tested (see Figures 10 and 11). The systems were investigated and described by Stria [47] and Korjenic et al. [8]

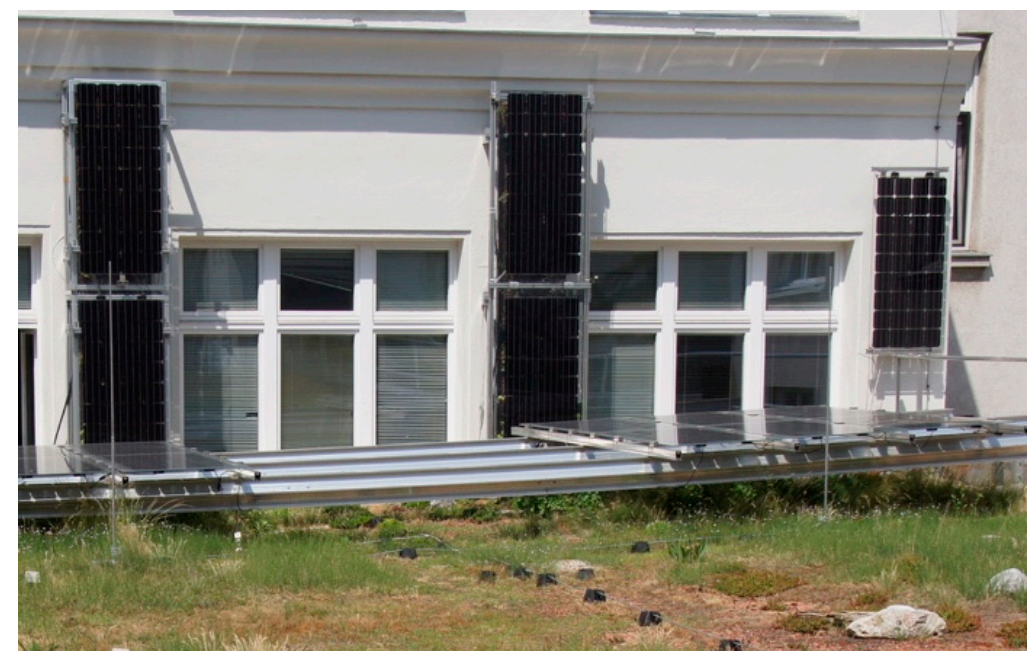

Figure 10. Photo of the living wall with vertical PV at Kandlgasse, Vienna, Austria (photo: Irene Zluwa). 


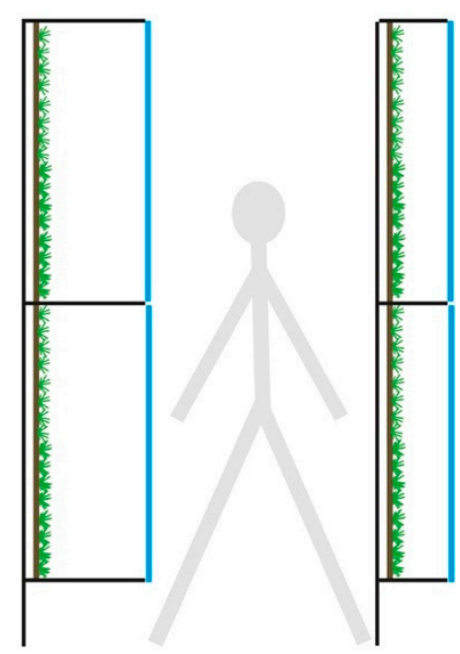

Figure 11. Schematic drawing of the living wall with vertical PV system at Kandlgasse, Vienna, Austria (sketch: Irene Zluwa).

Type of VG: The OPTIGRÜN living wall system is mounted on a steel sub-construction with a $5 \mathrm{~cm}$ large airgap to the wall. The lava-based substrate is held by a metal frame, the measurements of one module was $60 \times 100 \times 6 \mathrm{~cm}$. In each module, there were predefined holes for 18 plants. Eight different plant species were observed: Bergenia cordifolia, Festuca gautieri, Geranium sanguineum, Heuchera $\times$ cultorum, Sagina subulata, Sedum floriferum, Sedum reflexum and Sedum spurium.

PV types and mounting: A custom-made aluminium frame was used to hold semitransparent glass-glass PV panels. The measurements of the PV panels produced by SOLARWATT (Dresden, Germany) are $80 \times 160 \mathrm{~cm}$, their translucence is descripted with $32 \%$. In one test field, a distance of $25 \mathrm{~cm}$ between greenery and PV was given, in the second field, a larger distance of $45 \mathrm{~cm}$ was installed. Additionally, one of the custom-made frames provided an extra mechanism to open the PV construction in order to allow better accessibility to the subjacent greening for maintenance work.

Plant development influenced by PV: Sedum spurium and Sagina subulata showed a low vitality after the hot summer months, their suitability for this type of use is not given. Moderate vitality was recorded for Sedum reflexum, Geranium sanguineum and Sedum floriferum. Further testing of those species for this combination of VG and PV is recommended. Heuchera $\times$ cultorum, Bergenia cordifolia and Festuca gautieri showed the best results in vitality marks and can be chosen for further applications in similar systems.

When comparing the vitality of plants with regards to the influence of the distance, the results showed that plants in the system with $45 \mathrm{~cm}$ distance between the PV panels and the greening system were in a better condition than plants with $25 \mathrm{~cm}$ distance, especially in hot summer months. This effect may be in relation to hotter air temperatures, as well as likely being caused by less ventilation due to dense leaves of the plants in the narrow system.

Maintenance: In the narrow system with $25 \mathrm{~cm}$ distance between living wall system and PV panels, cutting and replanting was difficult. The system with $45 \mathrm{~cm}$ distance was easier to handle, yet still not very manageable. If the design is to involve more GR and PV panel combinations side by side, a hinged opening mechanism, like the suggested solution (see Figure 12), would be necessary.

(Estimated) energy output/thermal behaviour: In 2017, the energy output of the two PV green façade systems was measured (24 and $45 \mathrm{~cm}$ of PV to VG). In every single month, the yield of the variant with $45 \mathrm{~cm}$ distance was higher than the yield of the narrower system ( $25 \mathrm{~cm}$ distance). In total for the year $2017,163.78 \mathrm{kWh}$ of energy was generated with variant A ( $45 \mathrm{~cm}$ distance) and $158.08 \mathrm{kWh}$ with the variant B ( $25 \mathrm{~cm}$ distance). These results are surprising because the predicted yield from the forecast was lower for variant $4.5 \mathrm{~b}(45 \mathrm{~cm})$ than for variant $4.5 \mathrm{a}(25 \mathrm{~cm})$ due to slight shading on the panel caused by 
sun altitude and the surrounding building structure. Those results lead to the conclusion that a narrow distance from greenery to the panel was causing hotter temperatures in the PV cells and therefore a lower energy yield.
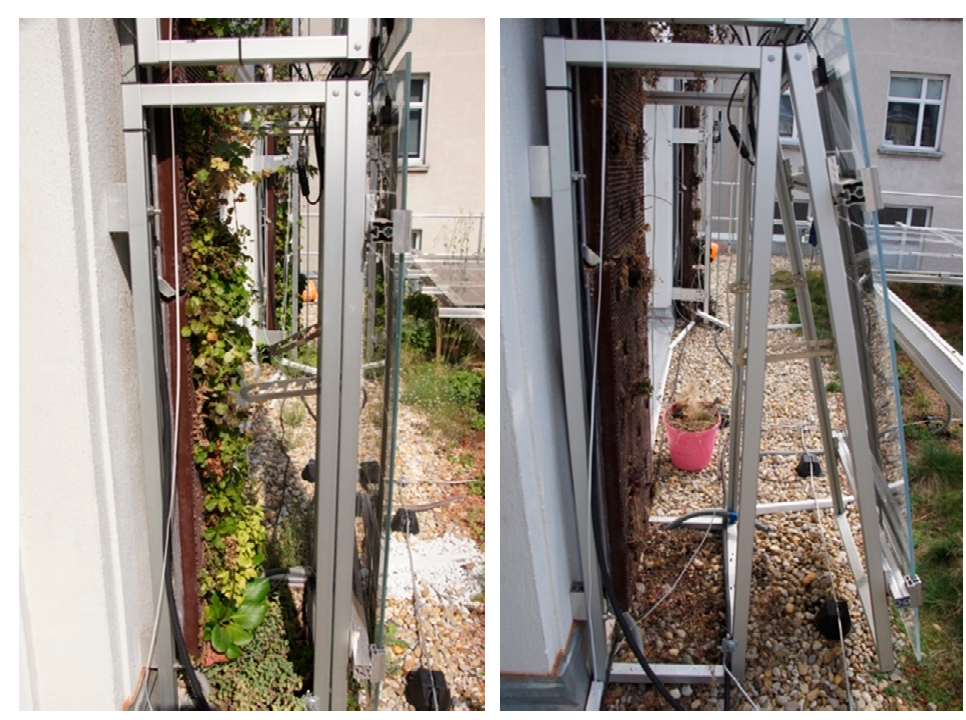

Figure 12. Opening mechanism for maintenance of the vertical greening system (photo: Irene Zluwa).

This could also be seen in the panel temperatures on hot summer days: on the reference module without green, the hottest temperatures were measured, followed by the panel with the narrow distance. The PV panel with a wider distance between the greenery and PV panels was the coolest [47].

\subsection{System 2 on a School Building in Vienna (Austria)}

Within the same project described in 4.6., another combination of BG and PV panels were tested: The second design is a horizontal PV system over an extensive green roof installed with a flat angle of $2^{\circ}$ resulting in a narrow, roof-like positioning of the PV panels (see Figures 13 and 14). The plant development and ground cover ratio were monitored. Air and soil temperature $\left({ }^{\circ} \mathrm{C}\right)$ and soil-moisture (Vol.\%) of the substrate were measured on the bare roof (full sun) and under the PV panels. Detailed information about used measurement plans and results were carried out in $[8,47,48]$.

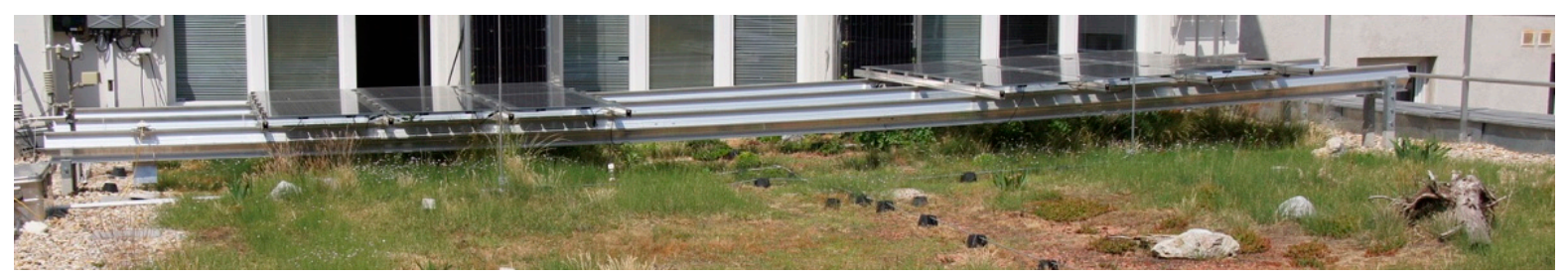

Figure 13. Photo of the GR PV system at Kandlgasse, Vienna, Austria (photo: Irene Zluwa).

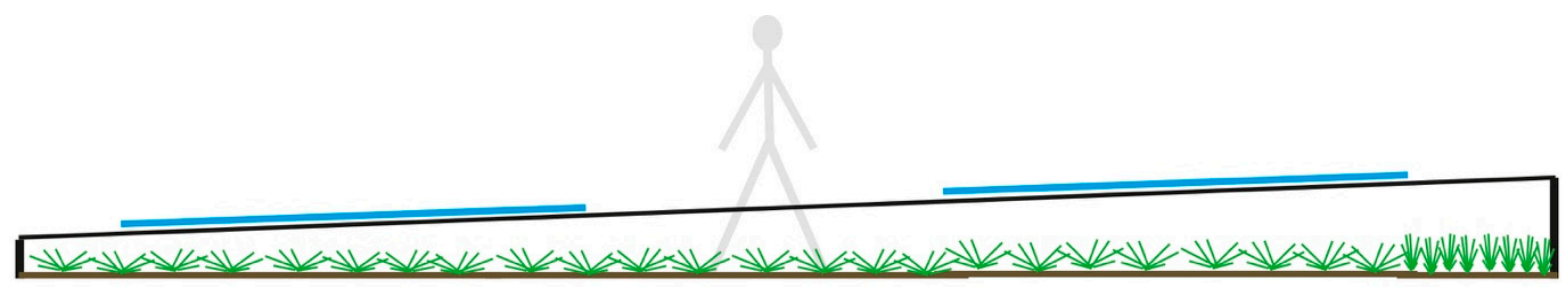

Figure 14. Schematic drawing of the GR PV system at Kandlgasse, Vienna, Austria (sketch: Irene Zluwa). 
Type of GR: The GR layers consists of a protection mat and a drainage board $(2.5 \mathrm{~cm})$ with an integrated filter fleece and a 5-20 cm top layer made of light soil for extensive green roofs (components: lava, pumice and compost). To avoid shading effects on the PV panels, only plant species of a height lower than $40 \mathrm{~cm}$ were chosen. Due to conditions under the PV panels, the implementation of the plants had to be done in two steps: First approach: extensive green roof with a seed mixture of pannonian dry-meadow species: sedum (Sedum acre, Sedum album, Sedum reflexum "Angelina", Sedum sexangulare), annuals and perennials (Ajuga chamaepitys, Allium flavum, Allium sphaerocephalon, Alyssum alyssoides, Alyssum montanum, Anthoxanthum odoratum, Campanula rotundifolia, Carex caryophyllea, Carlina vulgaris, Cerastium glutinosum, Cerastium pumilum, Draba verna, Festuca ovina, Festuca valesiaca, Genista pilosa, Gentianella austriaca, Helianthemum canum, Herniaria glabra, Hiracium pilosella, Holosteum umbellatum, Muscari neglectum, Ononis pusilla, Oxytropis pilosa, Petrorhagia saxifrage, Polygala comosa, Polygala major, Potentilla argentea, Primula veris, Pulsatilla grandis, Saxifraga tridactylites, Scorzonera austriaca, Seseli hippomarathrum, Teucrium chamaedrys, Thymus pannonicus agg., Veronica praecox [49]). In 2017 there was a second approach for planting under the PV panels tested: Anemone sylvestris, Ceratostigma plumbaginoides, Corydalis cheilanthifolia, Hypericum calycinum and Symphytum grandiflora were added under the panels as pot plants.

PV types and mounting: A custom-made horizontal PV system was designed for the project to investigate new strategies of combined PV panels and GR systems. Glass-Glass modules with a translucence of $32 \%$ were installed on horizontal steel beams mounted on the building. The beams had to support a span width of $10.1 \mathrm{~m}$ for bringing the load into the walls as the roof could not handle the weight due to static reasons. An inclination of $2 \%$ leads to a distance ranging from 50 to $70 \mathrm{~cm}$ between the GR and PV panels, which allows two testing fields. The system is east-west oriented.

Plant development influenced by PV: After the seeding in May 2016, it was observed that there was less sprouting in the PV-influenced areas than on the bare green roof. This could be caused by a lack of water reaching the space underneath the PV panels, as well as potentially limited sunlight. Therefore, in spring 2017 there was a second approach tested with potted plants under the PV panels. Additional irrigation was installed under one of the two testing fields and individuals of Anemone sylvestris, Ceratostigma plumbaginoides, Corydalis cheilanthifolia, Hypericum calycinum and Symphytum grandiflora were planted under the PV panels. After the implementation of potted plants, a sufficient ground cover-ratio under the PV panels was recorded. Anemone sylvestris did not survive at all. However, Hypericum calycinum did survive under the PV panels yet with low vitality. Symphytum grandiflorum showed negative results in the beginning, however, its vitality was raised continuously. The best results were shown by Corydalis cheilanthifolia and Ceratostigma plumbaginoides. Plants on the irrigated side of the PV panel testing fields were in better condition than the ones without irrigation. Additional irrigation can be recommended for this type of PV panel and GR combination.

Maintenance: A few species that were not seeded were recorded during the monitoring period, namely: Tripleurospermum inodorum, Silene vulgaris, Capsella bursa-pastoris, Thlaspi arvense, Arabitopsis thalian, Solidago sp., Erigeron sp., Populus alba and Acer campestre. Only the last two named herb species, as well as the wooden plants, were removed during maintenance processes once a year.

The type of low-mounted horizontal PV panels that were set close side by side (forming a roof) made it hard to maintain the GR. Cutting and removing plants could only be done from a crawling position. Additionally, a flash-protection cable was installed on the sides of the beams, turning the already difficult maintenance mission into an impossible one. Nevertheless, almost no plant shading on the PV panels was monitored. Only a few plants of Erigeron sp. and Solidago sp. could make their way through the little space between the panels. However, it was observed that this kind of solution does not avoid shading on the PV panels totally, especially not in the critical areas beside and in front of the panels. 
(Estimated) energy output/thermal behaviour: Effects of shading of the PV panels and their influence on temperature and moisture in the substrate during extreme weather were outlined. At noon, substrate temperatures on the green roof in full sun were up to $16.9^{\circ} \mathrm{C}$ higher than under the PV panels. The volumetric water content of the substrate under the PV panels was slightly decreasing from $5 \mathrm{Vol} . \%$ to $4 \mathrm{Vol} . \%$ in the period 26 May to 4 June 2017. In contrast, the volumetric water content of the green roof in full sun reached 0 Vol.\% on 29 May 2017. According to that, plants in full sun were dried out after this time period, while plants under the PV panels stayed green. Several findings could be seen in other hot and dry periods from 18 June to 25 June 2017 and from 29 July to 5 August 2017 [47].

Measurements of the substrate temperature under the PV panels and on the bare roof showed that the PV worked as a thermal buffer [48].

\subsection{Test Site of the Universidad Industrial de Santander in Bucaramanga (Colombia)}

The study described by Osma-Pinto and Ordóñez-Plata [9] was based on two experiments which investigated the height of the panels and the type of roofing with regards to their influence on air velocity (see Figure 15).

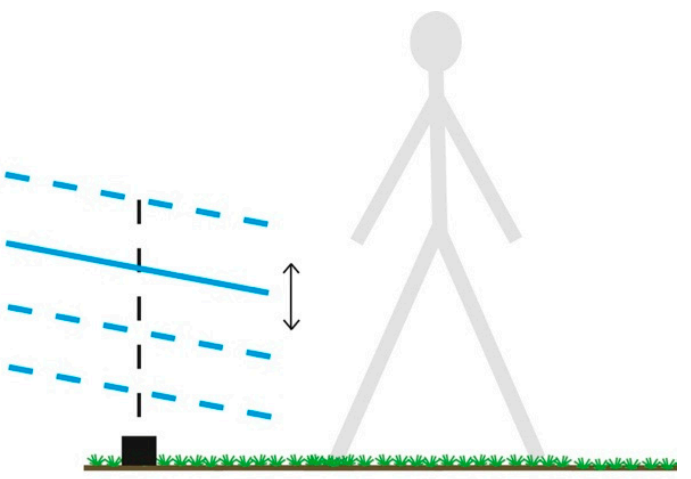

Figure 15. Schematic drawing of the setup at Universidad Industrial de Santander in Bucaramanga (sketch: Irene Zluwa).

Type of GR: The extensive GR consists of 8-10 cm substrate, covered with Sedum angelina, Sedum blue and Sedum sexangulare.

PV types and mounting: 23 polycrystalline PV panels (CANADIAN SOLAR, model CS6P-255) were installed on a customised metal construction (architectural aluminium and stainless steel) anchored to concrete blocks. The panels were adjustable to different heights $(25,50,75$ and $100 \mathrm{~cm})$ to allow a comprehensive observation of the influence of the system's height. The roof was made of concrete with a grey bitumen cover. The inclination of the panels was $10^{\circ}$.

Maintenance: The GR was irrigated to a "satisfactory moisture level in each green roof substrate" [9].

(Estimated) energy output/thermal behaviour: The higher the distance of the panel to the roof, the less of an influence was noted, however, this was only when air temperatures were higher than $31^{\circ} \mathrm{C}$. Between 20 and $31{ }^{\circ} \mathrm{C}$ the air temperature did not differ. The research group indicates that a panel installed at a height lower than $100 \mathrm{~cm}$ over a GR benefits from cooler air temperatures. Despite this, when measuring the real energy output, the PV panels with an installation height of $25 \mathrm{~cm}$ did benefit from the reflections of the grey roofing, compared to the PV panels on the GR. They could therefore compensate the energy loss of the higher operating temperatures. An installation height of 50 to $75 \mathrm{~cm}$ over a GR was recommended in the paper.

Experiments regarding the influence of air velocities indicate speeds over $1 \mathrm{~m} / \mathrm{s}$ enhance the energy generation for high solar radiations more than roof types or installation heights. 
Further information: The difficulties of measuring the PV output was specifically mentioned in the paper: a measurement error of $5 \%$ from the regular monitoring system occurred; these data were not analysed in the study.

\subsection{GR and PV Combination on ufaFabrik in Berlin (Germany)}

UfaFabrik is a cultural centre in Berlin Tempelhof (Germany). In the 1980s various green roofs were installed, different types of PV systems were added in 1998 and 1999 with the focus on research for enhancing PV technology (see Figures 16 and 17). The findings were reported by Köhler, Wiartalla and Feige in 2007 [32]. Additional information regarding the sub-construction and maintenance was collected in a personal interview with Werner Wiartalla [50].

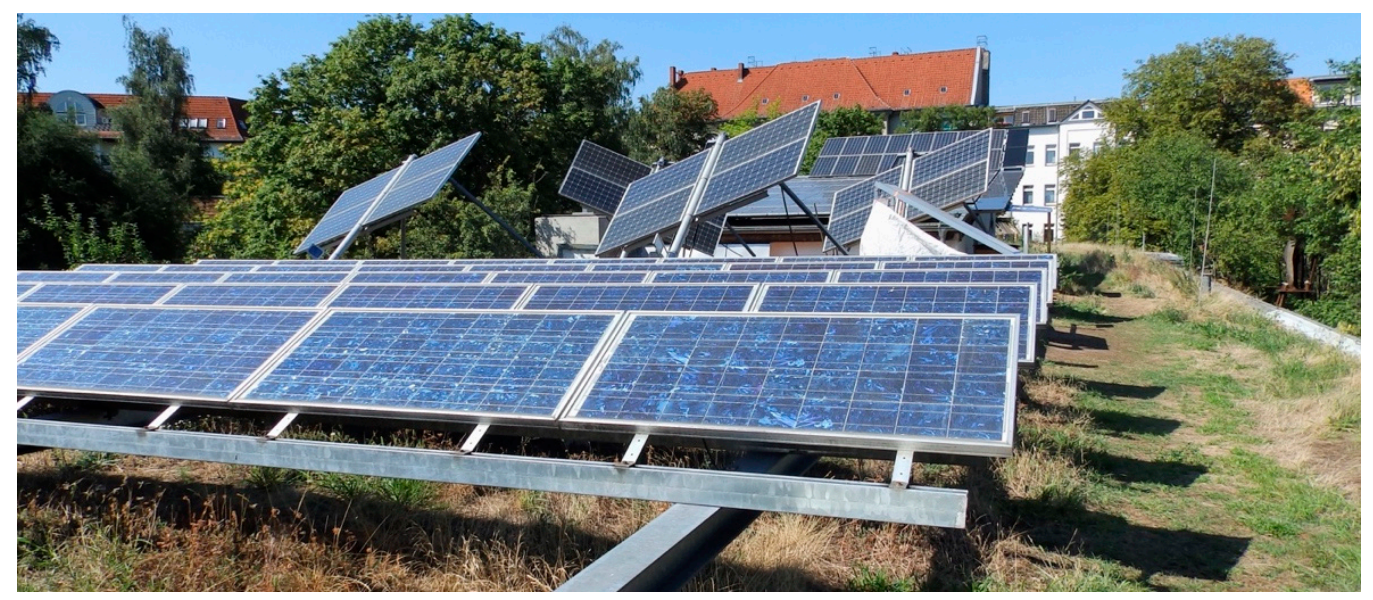

Figure 16. Photo of the PV systems at ufaFabrik in Berlin (Germany) (photo: Manfred Köhler).

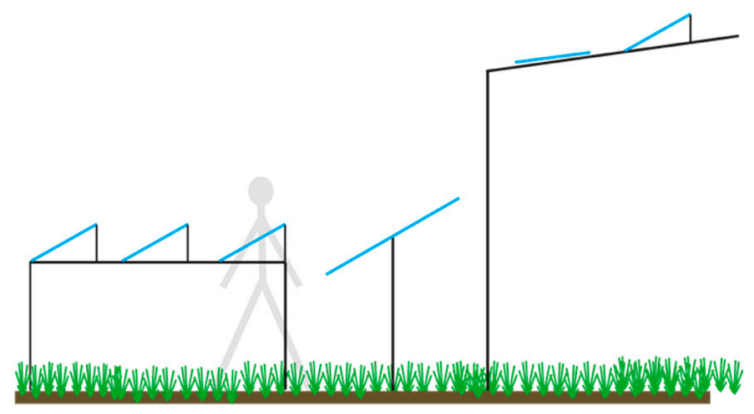

Figure 17. Schematic drawing of the PV at ufaFabrik in Berlin (Germany) (sketch: Irene Zluwa according to [32]).

Type of GR: The extensive green roofs with $10 \mathrm{~cm}$ growing medium were originally planted with sedum, yet now they show a wide variety of species.

PV types and mounting: On a customized metal sub-construction, PV panels are mounted with an angle of $30^{\circ}$. The sub-construction is connected to the building, the distance of the substrate surface and lower edge of the PV panels is approximately $100 \mathrm{~cm}$. As a reference, there are also PV panels placed on a bitumen roof, mounted with an angle of $30^{\circ}$ as well as an angle of $8^{\circ}$. All panels are southern oriented.

There are also three tracking systems with a distance of 50-120 cm from GR to PV panels. The tracking system moves $180^{\circ}$ with the sun (tracking via sensor, liquid or time).

Plant development influenced by PV: The shading of PV panels caused by plants leads to a decrease in sedum species, however, it supports the development of other species especially Erigeron annuus, Hypericum perforatum, Linaria vulgaris and Melilotus albus. The number of species increased on both GR during the period 1999 to 2006, whereas in the 
shade of the PV panels, a higher number of new species was reported. In addition, the total plant coverage and biomass was higher under the PV panels.

Maintenance: Low maintenance of the green roof was required (cutting of larger plants and removing of trees once a year), to prevent shading of the PV panels by plants. However, a high maintenance effort for the tracking system was mentioned in the paper.

(Estimated) energy output/thermal behaviour: The roof temperature was measured by infrared technology: on a hot, sunny day the bitumen roof had a maximum temperature of approximately $38^{\circ} \mathrm{C}$, the green roof showed a temperature of $22^{\circ} \mathrm{C}$ and on the roof in the shade of the PV panels a temperature of $19.5^{\circ} \mathrm{C}$ was recorded. This means that there is a significant difference between the roof temperature on a bitumen roof and a green roof (especially under the PV panels) on a hot day.

In the year 2004, PV panels on the green roof produced $8820 \mathrm{kWh}$ and the PV panels on bitumen produced $6.5 \%$ less than the PV panels on the GR. The best tracking module has an efficiency of $6 \%$ more than the regular PV panel on the GR, caused by higher efficiency in winter months. However, it was also reported that they require high maintenance and are sensitive to storm damage.

\subsection{Building on the Downtown Located St. George Campus of the University of Toronto in Toronto (Canada)}

A study by Jahanfar et. al. [10] investigated the effects of shade from PV panels on discharge reduction and plant growth (see Figure 18).
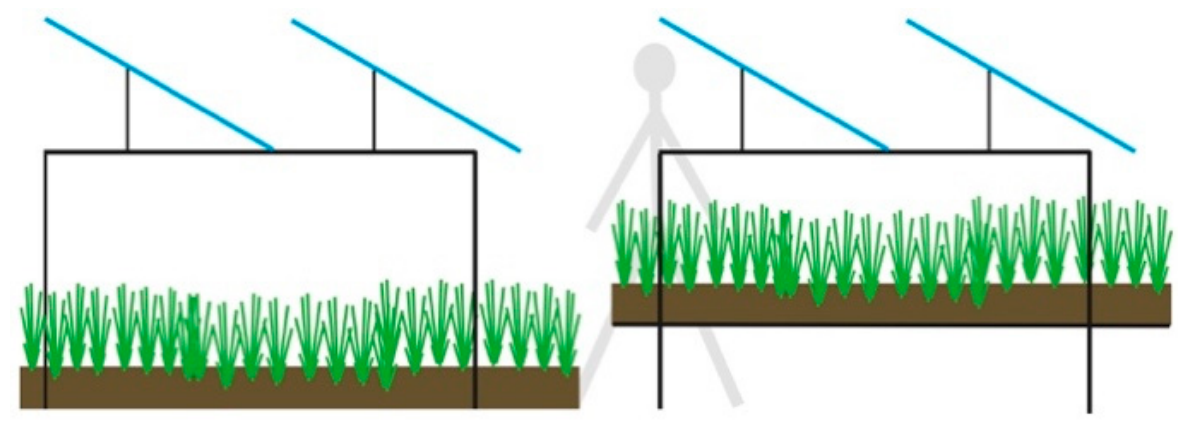

Figure 18. Schematic drawing of the PV green roof at University of Toronto (sketch: Irene Zluwa).

Type of GR: The GR was installed in trays filled with pine bark compost with less of $5 \%$ additional components in the height of $20 \mathrm{~cm}$. A mix of seeded native growing forbs and grasses was used for greening.

PV types and mounting: Two different heights of PV panels were tested. The height of the lower panel edge had a $60 \mathrm{~cm}$ distance between GR and PV panels, the higher module was mounted $1.20 \mathrm{~cm}$ above GR substrate.

Plant development influenced by PV: The leaves of the plants under the higher system $(120 \mathrm{~cm})$ were thicker and had smaller leaves, while the plants under the narrower system were thinner and had a larger surface area per leaf, caused by less exposure to light. In addition, there was more biomass under the higher PV panels than under the PV panels in the lower system. Both shaded areas were producing more biomass than the unshaded roofs (references).

Maintenance: The GR was irrigated with $1 \mathrm{~L} / \mathrm{m}^{2}$ per day via driplines.

(Estimated) energy output/thermal behaviour: There were no investigations on the energy output in this study.

Further information: In the case of rain events water flowed mostly down to the lower edge of the panel and concentrated the rainfall in a narrow strip along with the PV panel, causing locally saturated conditions, while the substrate under the PV panel stayed dry. Temporarily ponded water was noted frequently on the lower edge of the PV panels. In comparison to the other roofs referenced, there was $27-30 \%$ more runoff on the PV-GR. 


\subsection{U.S. EPA Region 8 Headquarters Building in Denver (USA, Colorado)}

The study of Jennifer M. Bousselot [51] shows the influence of PV on the growth of GR plants in Denver (see Figures 19 and 20). A GR with sedum-modules and PV was compared to the same setup without PV. Plant coverage, soil moisture and dry plant biomass were investigated.

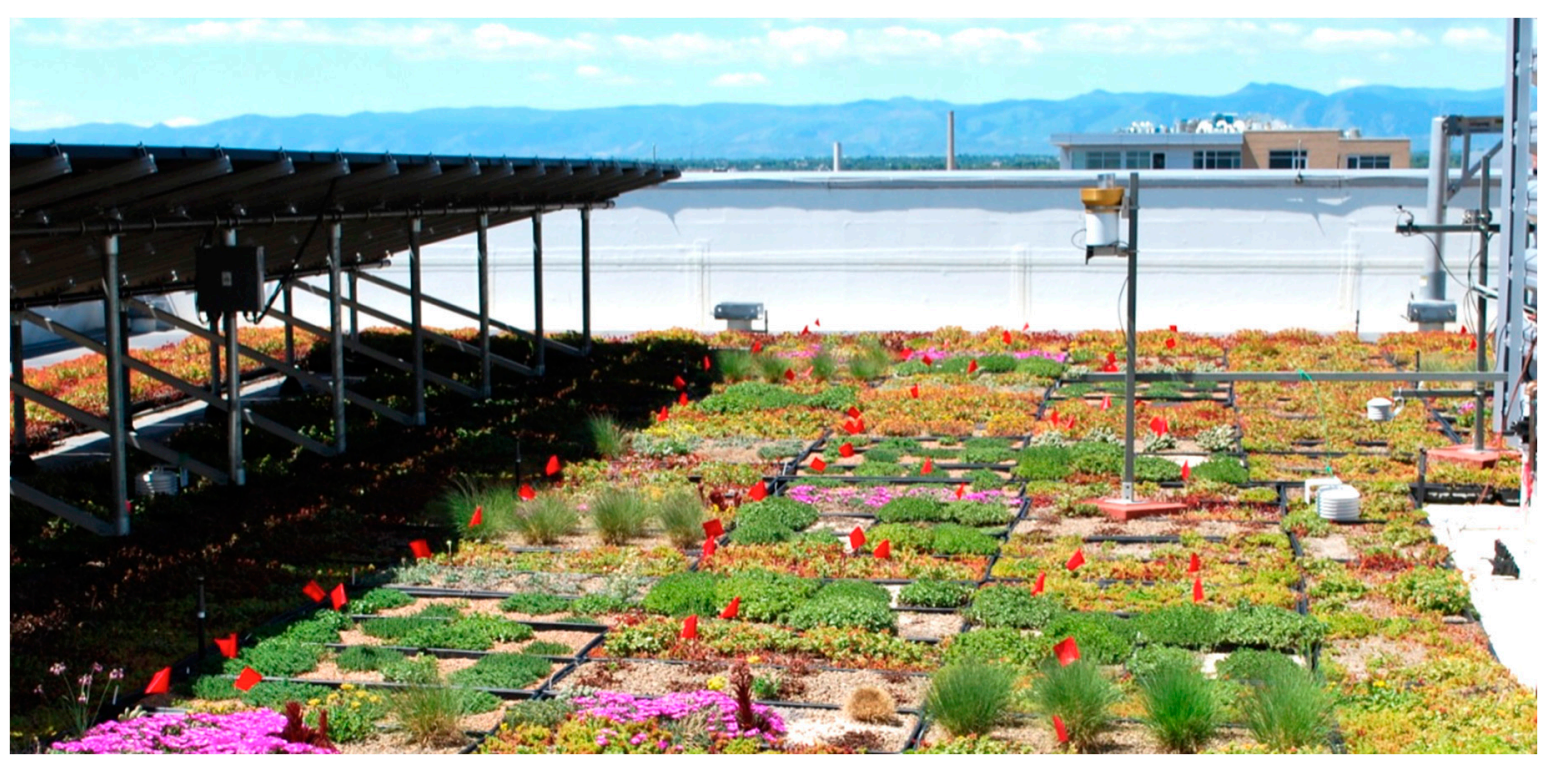

Figure 19. Photo of the PV green roof at the U.S. EPA Region 8 headquarters building in Denver, Colorado, USA [51] (photo: Thomas Slabe).

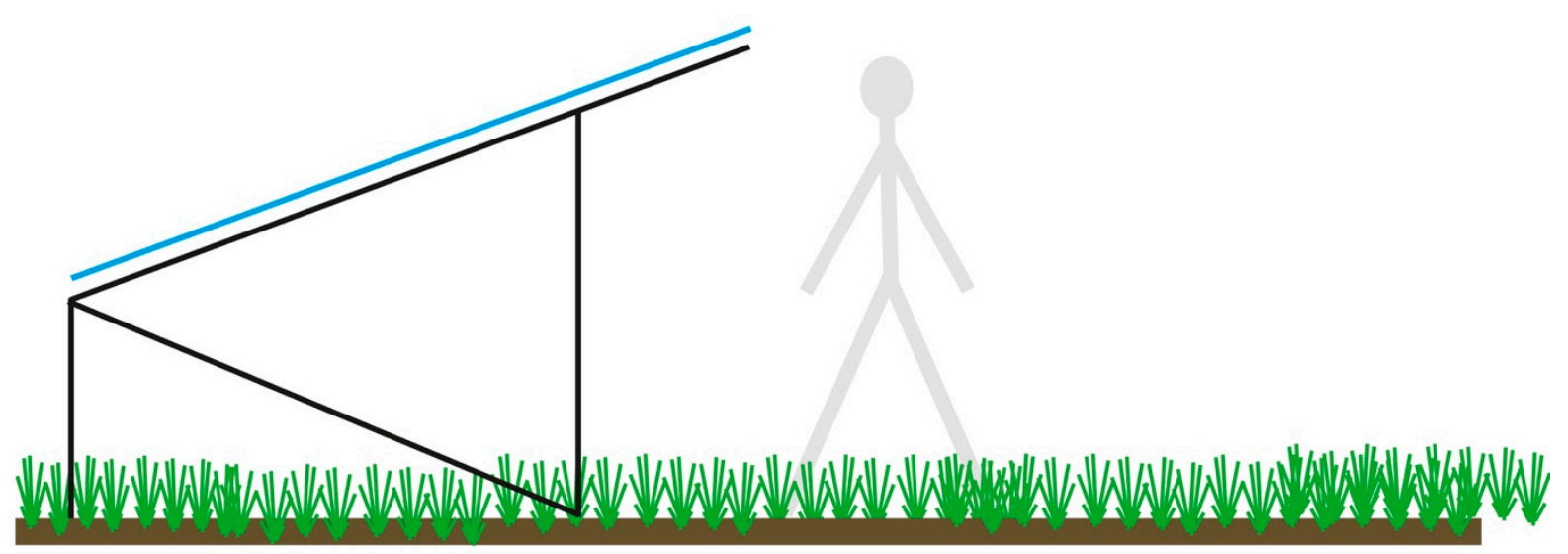

Figure 20. Photo of the PV green roof at the U.S. EPA Region 8 headquarters building in Denver, Colorado, USA [51] (photo: Thomas Slabe).

Type of GR: Black plastic trays (GreenGrid ${ }^{\circledR}$, Weston Solutions Inc., Vernon Hills, IL, USA) with the size of $61 \times 122 \times 10 \mathrm{~cm}$ were filled with two different kinds of substrates (A: heat expanded clay, peat, perlite and vermiculite; B: 50 Vol.\% Zeolite added to substrate variant A). Allium cernuum, Antennaria parvifolia, Bouteloua gracilis, Delosperma cooperi, Eriogonum umbellatum aureum, Opuntia fragilis, Sedum lanceolatum and Sempervivum "Royal Ruby" was planted in the trays. of $1.5 \mathrm{~m}$.

PV types and mounting: The PV was elevated on a metal rack structure at the height

Plant development influenced by PV: A higher plant coverage was reported in the area influenced by the PV panels, due to a better overwintering success (plants were protected from extreme temperatures and morning sun). The modules in the transition 
area between shaded and exposed GR contained thick clusters of Sedum spurium. More patchier plant growth was mentioned in so-called unprotected areas.

In the protected area, PV panels created partial morning shade, some protection from wind and increased thermal protection in winter. In these areas, more collections of snow were also recorded.

In the beginning of the experiment, when all the plants were still alive, the substrate moisture under the PV panels was higher in comparison to the bare GR. However, in contrast, further on in the experiment the effect was reversed, likely due to the lower ground cover ratio on the exposed GR (where there are fewer plants, less water is needed).

Maintenance: The GR was irrigated with drippers. Plugging issues of the drippers were mentioned.

(Estimated) energy output/thermal behaviour: No information was given in the paper.

4.12. PV Rooftop Garden Prototype at the University of Natural Resources and Life Science, Vienna in Vienna (Austria)

The vision of the PV rooftop garden project was to add an extra benefit to the combination of roof greenery and $\mathrm{PV}$ panels by providing space for human interaction under the PV panels [33]. In this design approach, the roof is constructed as a (semi)-intensive garden with a pergola-like sub-construction holding the PV panels. Therefore, it creates a shelter from rain and sun radiation (see Figures 21 and 22). The influence of translucent PV panels on plants were investigated [33,52-55]. A summary of the findings, a documentation of the design process and visualizations of potential applications on buildings were carried out by Sattler et al. [33] The increased thermal comfort of this solution for users of the rooftop was investigated by Weixelbaumer et al. [56,57]

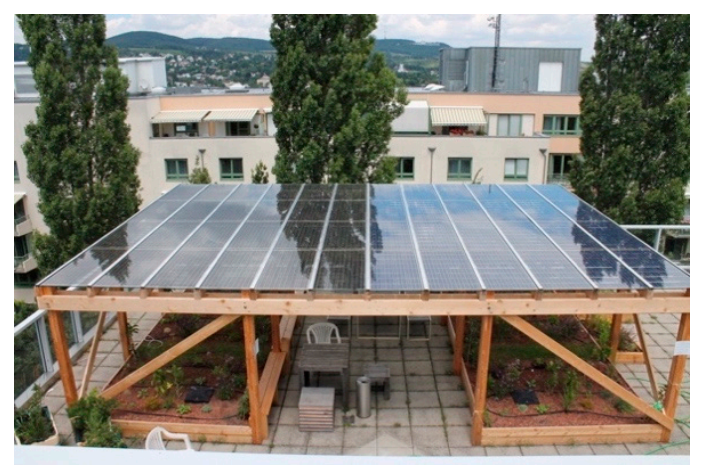

Figure 21. Photo of the PV roof garden test stand at University of Natural Resources and Life Science, Vienna, Austria (photo: Irene Zluwa).

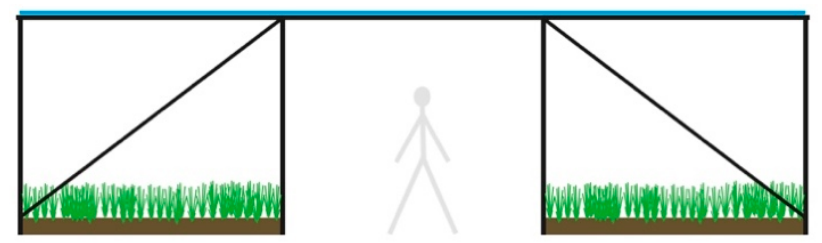

Figure 22. Schematic drawing of the PV roof garden test stand at University of Natural Resources and Life Science, Vienna (sketch: Irene Zluwa).

Type of GR: The vegetation layer of the rooftop garden is constructed as semi-extensive GR using $4 \mathrm{~cm}$ drainage layer (lava substrate), filter fleece and $16 \mathrm{~cm}$ of lightweight green roof substrate. Climbing plants, annuals, edible plants, perennials, herbs and grasses were planted.

PV types and mounting: Translucent glass-glass panels in two variants: (a: opaque cells with $27.84 \%$ transparency, b: special PV cells with holes and a transparency of $25.64 \%$ ) 
were mounted with aluminium rails on a pergola-like wooden sub-construction at the height of $2.60 \mathrm{~m}$.

Plant development influenced by PV: It was noticed that the horizontal PV panels were creating a shelter for the plants. Precipitation only affected the borders of the planting beds. In summer 2020, when irrigation was inactive during March and April, the plants on the southern side of the planting bed (exposed to the sun) were visibly dry. Plants in the shaded areas stayed green during the drought period [58].

The range of plants successfully growing in the PV roof garden was quite broad: in the lawn mixture it was noticed that the grass species developed very well, while the herbs only grew in the sunny borders of the PV panels. It was also stated that some ornamental plants showed less flowering success in the more shaded areas. Moreover, most of the edible plants need to be planted in the southern areas. It was specifically mentioned that the plants need irrigation, as there is no precipitation under the PV roof.

Maintenance: The PV roof garden is automatically irrigated via drip lines and maintained two times a year like a typical ornamental planting bed.

(Estimated) energy output/thermal behaviour: As visible in Figure 23, the measuring period began in May 2015. In 2016 and 2017 the annual produced energy was around 5.84 MWh. In 2018 the lower yield of 5.35 MWh was caused by technical issues in June and July. In 2019 the energy output was 5.90 MWh [59].

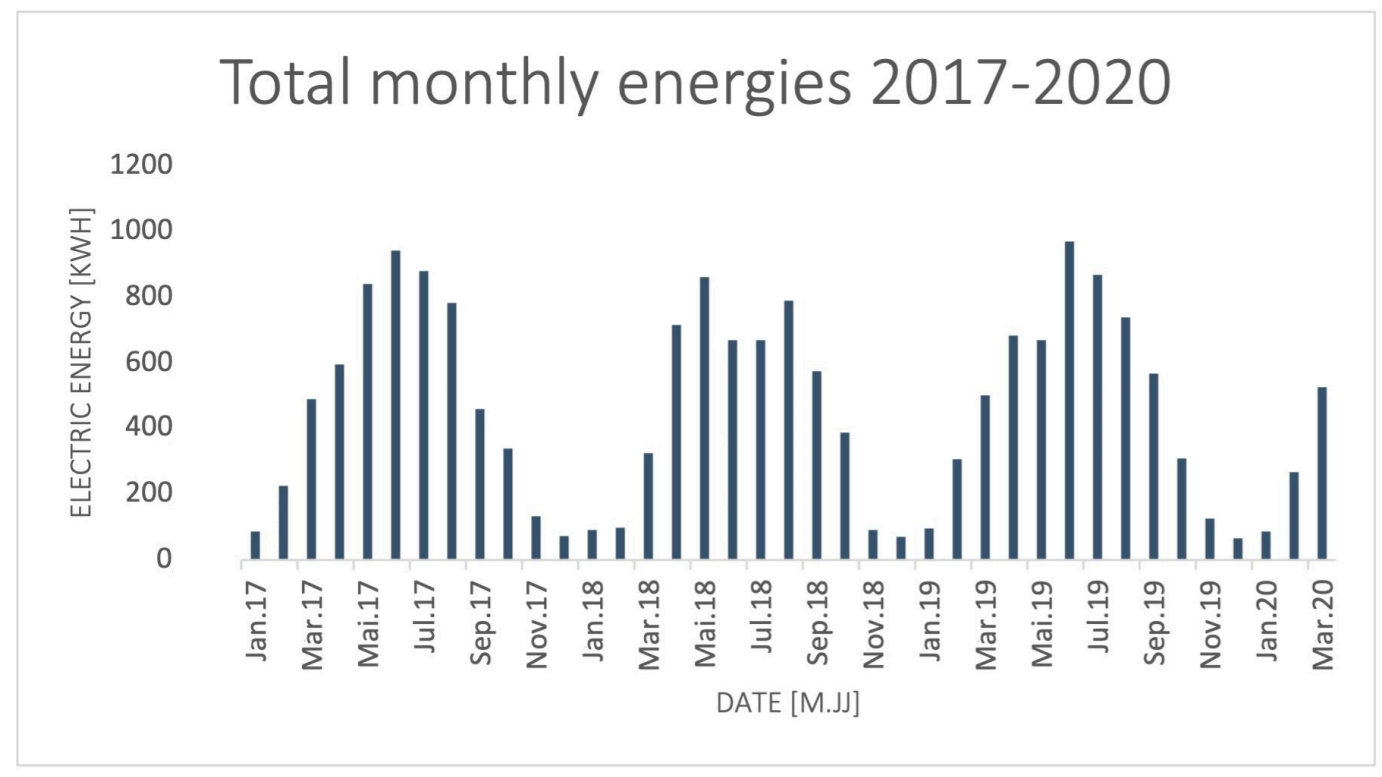

Figure 23. Power generated within the PV rooftop garden test site at University of Natural Resources and Life Sciences, Vienna from May 2015-March 2019 [59] (graph by ATB-Becker).

A vertical air temperature profile was also done at different heights $(2.10 \mathrm{~m}, 1.20 \mathrm{~m}$, $40 \mathrm{~cm}$ ): on hot summer days the coldest air temperatures were measured directly above the GR, the hottest directly under the PV panels [57].

Further information: Research on the thermal conditions for humans in the PV roof garden (by calculating the Universal Thermal Climate Index) showed that the diurnal amplitudes decreased under the PV panels (in comparison to the bare roof). This is leading to an optimal thermal comfort for the user of the roof: on a hot summer day, it feels around one heat stress class colder (from very strong heat stress to strong heat stress) under the PV panels, whilst in winter on a windless day without sun it feels warmer under the PV panels. The PV panels also protect against rain and snowfall. All these factors add an extra benefit for human comfort and extend the time they will wish to spend on the roof $[56,57]$. 


\section{Results and Discussion}

The combination of BG and PV energy production seems to be a fruitful combination for a holistic design of contemporary buildings. To reach the full potential of energy efficiency from the combination of both systems and turn the challenges into opportunities, the advantages as well as occurring problems in the specified designs were analysed and summarised into a matrix (see Figure 24).

\begin{tabular}{|c|c|c|c|c|c|c|c|c|c|}
\hline \multicolumn{10}{|c|}{ Matrix of advantages and disadvantages in the reviewed BGPV systems } \\
\hline System & $\begin{array}{l}\text { Distance } \\
\text { substrate-PV }\end{array}$ & PV inclination & Type of GR/VG & $\begin{array}{l}\text { Mounting: } \\
\text { Synergy of } \\
\text { greening system } \\
\text { and PV } \\
\text { subconstruction }\end{array}$ & $\begin{array}{l}\text { Standard } \\
\text { (subconstruction) } \\
\text { PV-System }\end{array}$ & Maintenance & $\begin{array}{l}\text { Irrigation } \\
\text { recommended }\end{array}$ & $\begin{array}{l}\text { Advantages for } \\
\text { plants given }\end{array}$ & $\begin{array}{l}\text { Inproovement on } \\
\text { energy } \\
\text { production/lower } \\
\text { air temp }\end{array}$ \\
\hline $4.1 \mathrm{a}$ & $5 \mathrm{~cm}^{* *}$ & $15^{\circ}$ & ext. GR & no & yes & high & no & & not significant \\
\hline $4.1 \mathrm{~b}$ & $12 \mathrm{~cm} * *$ & $20^{\circ}$ & ext. GR & yes & yes & high & no & & not significant \\
\hline $4.2 \mathrm{a}$ & $12 \mathrm{~cm}$ & $30^{\circ}$ & ext. GR & no ** & no & & no & & yes \\
\hline $4.2 \mathrm{~b}$ & $18 \mathrm{~cm}$ & $30^{\circ}$ & ext. GR & no $* *$ & no & & no & & yes \\
\hline 4.3 & $30 \mathrm{~cm}$ & & semi int. GR & no & no & high & yes & no & no \\
\hline 4.4 & $40 \mathrm{~cm}$ & $90^{\circ}$ & & yes ** & no & practicable & no & & yes \\
\hline 4.5 & $45 \mathrm{~cm}$ & $90^{\circ}$ & VG: climbers & no * & no & & yes & & yes \\
\hline $4.6 \mathrm{a}$ & $25 \mathrm{~cm}$ & $90^{\circ}$ & VG: living wall & no * & no & difficult & yes & no & yes \\
\hline $4.6 \mathrm{~b}$ & $45 \mathrm{~cm}$ & $90^{\circ}$ & VG: living wall & no * & no & moderate & yes & no & yes \\
\hline 4.7 & $50-70$ & $2^{\circ}$ & ext. -semi int. GR & no * & no & difficult & yes & yes and no & \\
\hline $4.8 \mathrm{a}$ & $25 \mathrm{~cm}$ & $10^{\circ}$ & ext. GR & no & no & & yes & & \\
\hline $4.8 \mathrm{~b}$ & $50 \mathrm{~cm}$ & $10^{\circ}$ & ext. GR & no & no & & yes & & yes \\
\hline $4.8 \mathrm{c}$ & $75 \mathrm{~cm}$ & $10^{\circ}$ & ext. GR & no & no & & yes & & yes \\
\hline $4.8 d$ & $100 \mathrm{~cm}$ & $10^{\circ}$ & ext. GR & no & no & & yes & & \\
\hline $4.9 \mathrm{a}$ & $100 \mathrm{~cm}$ & $30^{\circ}$ & ext. GR & no * & no & low & yes & yes & yes \\
\hline $4.9 \mathrm{~b}$ & $50-120 \mathrm{~cm}$ & $90^{\circ}$ (Tracking) & ext. GR & no * & no & high (PV) & no & & \\
\hline $4.10 \mathrm{a}$ & $60 \mathrm{~cm}$ & & semi int. GR & no & & & yes & yes & \\
\hline $4.10 \mathrm{~b}$ & $120 \mathrm{~cm}$ & & semi int. GR & no & & & yes & yes & \\
\hline 4.11 & $150 \mathrm{~cm}$ & & ext. GR & no & no & & yes & yes & \\
\hline 4.12 & $260 \mathrm{~cm}$ & $2^{\circ}$ & semi int. GR & yes & no & high & yes & yes & \\
\hline
\end{tabular}

Figure 24. Matrix of opportunities and challenges of the reviewed BG and PV systems (see Section 2.3, step 3) Variants of systems are marked with $a, b, c, d$.

The matrix describes:

- Distance substrate (surface) to (lower) PV panel (side): This criterion shows the "air space" between the PV panel and vegetation layer. Plant height is not taken into account.

- PV-inclination: The angle of the PV panel is also listed. Both criteria (distance and PV inclination) allow a quick description of the system interactions.

- Type of green roof (GR) and vertical green (VG): The construction height of GR defines the different categories for green roofs according to the definition given in Section 3.1.1. For better understanding, extensive GR are presented in regular font, semi-intensive GR were marked bold, due to their higher environmental background. The evaluation of vertical green is done similarly: more shallow systems are described in regular font, systems with a substrate layer higher than $15 \mathrm{~mm}$ are marked in bold.

- Synergy of greening system and PV: This point considers whether the substrate is used as an additional weight as a ballast for the PV panels against wind loads, to avoid the need of extra weight or roof penetration to fix the PV system to the building. Furthermore, according to this, the sub-construction for VG (climbing aids or living wall systems) could be used instead of an extra sub-construction for the PV panels. If material could be reduced because of the synergy of both systems (BG and PV), it is highlighted in bold font.

- Standard (sub-construction) PV system: The systems, those that are already (prefabricated) available on the market, are highlighted bold, and customized systems are shown in regular font. 
- Maintenance: Information about the maintenance of BG and PV are given in this section. If the maintenance was labelled as low or practicable, the findings are marked in a bold font. If there was a high maintenance effort necessary, or the access for maintenance work was difficult, the text is written in regular font.

- Irrigation recommended: Projects that were irrigated or would recommend irrigation are highlighted bold, not-irrigated projects are described in regular font.

- Advantages for plants given: If benefits for the plants due to the protecting effects of the PV were mentioned in the analysed publication, data are highlighted bold, if there were disadvantages, a regular font is used.

- Improvement on energy production/lower air (or PV-panel) temperatures: Positive interactions of BG and PV leading to increased energy production (compared to a PV system without plants) were highlighted in bold, negative effects are marked in regular font.

Regarding the findings of the reviewed studies supplemented by additional literature, the following principles about the design of BG in combination with PV energy production can be derived:

\subsection{Design of Greening System and Selection of Plants}

Only the systems with higher distances $(>60 \mathrm{~cm})$ between substrate surface and PV panels $(4.7,4.8 \mathrm{c}+\mathrm{d}, 4.9 \mathrm{a}+\mathrm{b}, 4.10 \mathrm{a}+\mathrm{b}$ and 4.12$)$ report advantages for the plants due to less evaporation in the shade of the panels. At lower distances, the limited radiation [10] and limited ventilation [9] may be an issue for the development of plants. Translucent PV panels as used in 4.4, 4.5, 4.6, 4.7 and 4.12 could allow better light conditions for the plants. In addition, limited water availability under the panels was reported in the investigation of Jahanfar [10]. In system 4.7 [47], more positive development of the plants was reported when the system was irrigated.

As seen in the high maintenance effort (cutting of vegetation around the panel) Schindler [44] reported for the semi-intensive GR system 4.3, low sub-construction heights require shallow substrates to avoid shade of plants on the PV panels. Other authors, such as Brenneisen [60], suggest modelling of the substrate heights $(7 \mathrm{~cm}$ in front of the PV panel, $12 \mathrm{~cm}$ behind the PV panel). Some companies (for example OPTIGRÜN) [37] do recommend a layer of gravel in front of the panel to prevent shading on the panel. Köhler et al. [32] were reporting an enhancement of species richness under the PV panels, Schindler et al. [44] could not see this effect in their study. In system 4.7, Stria 46 reported that the shelter made of the PV panels was advantageous for the plants; a similar causality was mentioned by Bousselot et al. [51] regarding system 4.11.

Only a few publications $[7,33,47,54,55]$ were investigating the development of specific plant species under the PV panels. Certainly, more research should be done in this sector for different climate zones. General criteria for the selection of plants regarding the combination of an extensive PV-GR system were found in a publication from Lamnatou and Chemisana [7]: According to them, the plants should have shallow roots (as the growing medium is $<20 \mathrm{~cm}$ ), the chosen plants should require low maintenance (low irrigation and nutrification) and should be resilient to diseases and pests. In addition, they should also be resistant to rough weather conditions (direct solar radiation, drought, frost and wind). Moreover, they should show a positive interaction with the PV panels because of high albedo (see system 4.4), and the building (dense foliage with thick leaves and dense canopy in general create an insulating layer of air volume below the leaves). Furthermore, the interaction with the environment should be considered with respect to the reduction of a UHI-effect, absorption of stormwater, mitigation of air pollution, pollinators, urban biodiversity, noise pollution, medicine, urban agriculture and finally aesthetics [7].

For semi-intensive and intensive GR and PV systems, higher sub-construction heights are recommended (see Section 5.2). As shown in the PV rooftop garden project (4.12), with semi-intensive and intensive GR PV systems, the use of a broad spectrum of plants is possible. The species can be selected regarding the needs of the users (low maintenance, 
food production, ornamental roof garden etc.) For the selection of the plants, it is important to be informed about the light distribution on the roof [33].

Regarding the selection of species for VG and PV systems, only two systems were analysed: one with climbing plants (4.5) and one living wall system (4.6). More research in this sector needs to be done.

In most of the publications, systems were irrigated $(4.6,4.7,4.8,4.10,4.11,4.12)$, or irrigation was recommended [44,47]. Irrigation is not the goal in extensive systems (4.1, $4.2,4.4,4.9)$ since they should sustain with minimum maintenance. However, regarding an enhancement of the PV energy production, irrigation could be considered even for extensive systems (see Section 5.3).

If the combination of BG and VG is artificially irrigated, the use of alternative water resources (rainwater, greywater) should be considered for saving drinking water resources [25].

\subsection{Interaction between Construction and Maintenance Efforts}

Most of the examples showed a combination of extensive GR with horizontal PV panels (with a distance $<50 \mathrm{~cm}$ between GR surface and PV panels). Baumann et al. recommended the development of an optimized mounting system [40], in a later publication a distance of $40 \mathrm{~cm}$ (for the system with bifacial cells) was chosen [6]. Wiartalla [50] reported that system $4.9 \mathrm{a}$, with a distance of $100 \mathrm{~cm}$, required a low maintenance effort.

In the review process, there was no intensive GR found, yet three examples with $20 \mathrm{~cm}$ substrate (semi-intensive GR) could be identified. There was only one semi-intensive GR system with a distance of less than $30 \mathrm{~cm}$ of GR to the PV panel (4.3). The report for this kind of combination [44] indicates high maintenance efforts with regards to the need to cut vegetation in front, below and at the sides of the PV panels, in order to avoid shade on the panels. For the other semi-intensive GR example 4.12 (PV rooftop garden) the maintenance effort is labelled high, due to the visual aspects of ornamental planting, not due to issues with shade on panels caused by GR vegetation [58].

Only two projects (4.5 and 4.6) investigated the combination of VG and PV panels/system/energy production. For the system with climbing plants and PV panels (4.5), no information about maintenance efforts was given. For the living wall and PV system, it was mentioned that the system with a wider distance of $45 \mathrm{~cm}$ (4.6 b) was easier to maintain than the narrower system with $25 \mathrm{~cm}$ (4.6 a). Nevertheless, an opening mechanism was recommended [8].

For system4.7, it was reported that cables were hindering the maintenance of plants. In addition, the lower, horizontal array of the panels was difficult to maintain and the central area was not reachable [8].

As an innovative aspect, Baumann et al. [6] suggested the investigation of automatized mowing robots for the maintenance of GR-PV systems.

As shown in the examples $4.1 \mathrm{~b}, 4.4$ and 4.12, the GR construction with different layers and technical soil acts as an additional weight for the PV panels, securing them against wind loads. Nevertheless, most of the sub-constructions were connected to the building $(4.5,4.6 \mathrm{a}, 4.6 \mathrm{~b}, 4.7,4.9 \mathrm{a} 4.9 \mathrm{~b})$ or concrete blocks as extra support were used $(4.1 \mathrm{~b}, 4.3$, $4.8 \mathrm{a}-\mathrm{d})$.

One project [40] utilized the standard products available on the market (namely by HILTY (4.1 a) and ZINCO (4.1 b)) for sub-construction. It is indicated that this is also due to the experimental character of the studies, on the one hand for a quick change of system heights as in $[9,42]$. On the other hand, some studies were explicitly done to develop new design solutions for a combined system and used therefore customized prototypes $[6,8,33,45]$. New design approaches were bifacial cells/panels mounted vertically (system 4.4), designs for the combination of VG and PV panels (system 4.5, 4.6 a, 4.6 b) and a pergola-like sub-construction (4.12).

Only two sub-constructions were made of wood (4.5 and 4.12), mainly due to the prototype character. Nevertheless, it is mentioned in the design study that the sub-construction 
can be made from a combination of stainless steel and aluminium or wood and aluminium. In every case, the rails of the mounting system for the PV panels are anyway made of aluminium [33]. The other projects used steel or aluminium as sub-construction material, or a combination of both. It can be stated that the use of substrate as a weight load to fix the PV panels is possible [33,38]. The advantage is that there is no penetration of the roof membrane and no extra weight needed. However, there are not many prefabricated ready-to-install systems on the market [61], and not even one supporting an intensive GR higher than $15 \mathrm{~cm}$ (substrate height). Development in this sector is strongly needed in order to offer a more cost-effective combination. No synergy of climbing aid or living wall system as a sub-construction for vertical PV panels could be found in the conduced review of examples.

Except for the tracking system (4.9 b), there was no maintenance effort for the PV system reported. Investigations about higher dust coverage on the PV caused by the greenery showed no negative effects [44].

\subsection{Improvement in Energy Production}

All publications that investigated the cooling effects of greening system on PV panels reported a positive interaction [6,8,9,32,40,42,45], except Schindler et al. [44], who mentioned that no cooling occurred because the substrate was dry in summer. Lamnatou and Chemisiana also pointed out in their study that a wet substrate is important for providing a cooling effect for PV panels [7].

Ogaili [42], as well as Osma-Pinto and Ordoñez-Plata [9], found out that the cooling effect decreases with increasing heights of PV panels. Vice versa, if the distance was too narrow, less air circulation leads to hotter temperatures under the panel.

\subsection{Key Findings for the Planning of Combined Building Greenery and Photovoltaic Systems}

- $\quad$ BG and PV systems with low sub-construction heights require shallow substrates and low growing plants to avoid shade on the panels. The substrate can also be modelled to a lower height in front of the panel and to a higher one behind it.

- In the case of the combination of a semi-intensive GR, a distance of $60 \mathrm{~cm}$ in minimum is recommended (or else high maintenance should be expected). With intensive GR-PV systems, the use of a broad range of plants is possible (depending on user needs); however, this is limited due to the gradient of shading of PV panels and the height of sub-construction.

- Pergola-like sub-constructions can improve the sojourn quality on the roof for the user.

- Maintenance must be considered in the design of sub-construction. Cables must be installed properly. Mobile parts of the construction need more maintenance than fixed installations.

- To avoid penetration of the roof membrane, GR substrates can be used to secure PV panels against wind loads. Statics of the roof and wind load must be calculated with regards to the height of the building as well as local conditions.

- A combined sub-construction for PV and VG systems would be effective for minimizing anchor points in the façade. Furthermore, accessibility, in order to maintain plants under PV panels, must be considered.

- Intensive GR-PV combinations and living wall systems require irrigation. Semiintensive and extensive GR-PV systems could consider additional watering to create more optimal conditions for plants as well as enhancement of the evapotranspiration process.

- The cooling effect of an extensive GR stops at a distance of around 75-100 cm.

- The cooling strongly depends on air velocity under the panel: Narrow system heights do not allow good air velocity and therefore store more hot air under PV panels.

- If the substrate is dry, there is no evapotranspiration and therefore no cooling. In hot and dry climate zones irrigation of the system should be considered, in order to 
enhance PV performance as well as cooling of the building below. Alternative water resources (rainwater, greywater) can be used to save drinking water resources.

\subsection{Future Research Directions}

- Development of standardized sub constructions adapted for semi-intensive and intensive GR.

- Observation of systems for the integration of alternative water resources (rain water/greywater) for an enhancement of the PV production, cooling effects and plant development.

- More research in the deployment of substrate material: there is the need for a lightweight substrate for (industrial) buildings with little weight load capacity. Moreover, the focus should go to recycled and local substrate components.

- The interaction of the shade of the PV-panels with different plant species (especially for agricultural applications) needs more investigation.

\section{Conclusions}

As can be observed in the results of the study, there is a spectrum of different designs for PV and BG systems suitable for different applications, aims and surfaces. The combination of different sub-constructions, panel types and variations of greening systems is a promising way of creating new exteriors for holistic buildings.

For the planning of BGPV systems, the following main findings could be summarised:

- $\quad$ BG and PV systems with low sub-construction heights require shallow substrates/low growing plants, whereas in the case of the combination of (a semi)-intensive GR system, a distance of a minimum $60 \mathrm{~cm}$ between the substrate surface and the lower panel edge is recommended; in case of an accessible roof garden, pergola-like subconstruction improve the quality of perception and comfort of users. The cooling effect of the greenery depends on the distance between the PV and the air velocity;

- If the substrate is dry, there is no evapotranspiration and therefore no cooling effect;

- There is a spectrum of different PV systems, sub-constructions, and plants for the combination of $\mathrm{BG}$ and $\mathrm{PV}$, which are suitable for different applications shown within the publication.

Different building types and functions of buildings will lead to different design goals: in industrial areas, buildings typically do not support high weight loads. Furthermore, in such areas, energy production will be more the focus as opposed to intensive roof gardening. In this case, extensive GR systems with low sub-construction heights would be the optimal choice. In contrast, regarding residential building accessibility and usability for the inhabitants should take centre stage. In this case, (semi-)intensive roof gardens with a PV pergola construction, enhancing an extra thermal comfort for users could be suggested. Inaccessible parts of roofs could be equipped with extensive GR-PV systems to optimise costs. In buildings intended for representational purposes, where costs are often not a limiting factor, a maximum variability of GR-PV systems can be planned, in which parts of the façade are covered by combinations of VG and PV. Additionally (bifacial), vertical panels could replace required railings on the roof.

Despite these vital findings and practical developments, there are still several points to consider regarding research and improvement of environmental impacts: According to Pearlmutter et al. [62], green does not always mean sustainable. A careful life-cycle analysis could be used to analyse each project in order to identify potential optimization and best practices. In life-cycle analysis, PV roofs have a higher negative impact than roofs without PV panels in the phase of material manufacture. In addition, GR with PV panels show a higher impact than gravel roofs with PV panels due to specific GR layer material such as drainage and filters [34]. The use of local substrates is preferable in order to avoid long transport routes and thereafter extra emissions. Furthermore, plastic drainage systems could be replaced by loose drainage material. With regards to the irrigation of the BG-PV systems, alternative water sources should be considered [25]. More environmentally 
friendly disposal methods for PV cells and other components are needed [34]. For a broader implementation, cost-effectiveness should be optimised, for example, by subsidies from the government, inclusion of social benefits, reuse of waste materials, innovative policies and much more [34].

In conclusion, more research needs to be done within the sector of building greenery and photovoltaic energy production, however the process of a holistic thinking for design and construction has already begun. In order to make use of the synergy of BG and PV more design solutions (also regarding aesthetic issues) need to be developed, tested and carried out in lighthouse projects, to gain visions for holistic contemporary and future architecture.

Author Contributions: I.Z. was the main author of the article, supervised by U.P., who was also strongly involved in the structuring process of the paper. All authors have read and agreed to the published version of the manuscript.

Funding: This research includes results of projects funded by the Austrian Research Promotion Agency, Division 2: Science/Industry Cooperation, Grillparzerstrasse 7, A-1010 Vienna, Austria (GreenPlusSchool@Megalopolis: Efficient living walls and green roofs combined with photovoltaican optimal solution for energy efficiency and in view of ecology/project number: 850124; Innovative concepts for energy producing green roofs/project number: 867 841060). Open access funding provided by BOKU Vienna Open Access Publishing Fund.

Data Availability Statement: No new data were created or analysed in this study. Data sharing is not applicable to this article.

Acknowledgments: The authors want to thank Gernot Becker (ATB-BECKER GmbH), Jennifer Bousselot, Andreas Dreisiebner, Markus Klenk, Manfred Köhler, Azra Korjenic, German Alfonso Osma Pinto, Nicole Pfoser, Thomas Slabe, Fabian Stria and Werner Wiartalla for providing additional data, footage and copyright for this publication.

Conflicts of Interest: The authors declare no conflict of interest.

\section{References}

1. Schwaiger, H.N.B.D.; Gallaun, H.; Zuvela-Aloise, M.; Andre, K. Reduktion staedtischer Waermeinseln durch Verbesserung der Abstrahleigenschaften von Gebaeuden und Quartieren (KELVIN). In Berichte aus Energie- und Umweltforschung, I.u.T; Bundesministerium fuer Verkehr; Federal Ministry Republic of Austria: Vienna, Austria, 2018; p. 95.

2. Brandenburg, C.; Damyanovic, D.; Reinwald, F.; Allex, B.; Gantner, B.; Czachs; Morawetz, U.; Kömle, D.; Kniepert, M. Urban Heat Islands Strategieplan; Municipal Department 22-Environmental Protection in Vienna (MA 22): Vienna, Austria, 2015.

3. Scharf, B.; Zluwa, I. Case study investigation of the building physical properties of seven different green roof systems. Energy Build. 2017, 151, 564-573. [CrossRef]

4. Tudiwer, D.; Korjenic, A. The effect of living wall systems on the thermal resistance of the façade. Energy Build. 2016, 135, 10-19. [CrossRef]

5. Nations, U. Paris Agreement; United Nations: Paris, France, 2015.

6. Baumann, T.; Nussbaumer, H.; Klenk, M.; Dreisiebner, A.; Carigiet, F.; Baumgartner, F. Photovoltaic systems with vertically mounted bifacial PV modules in combination with green roofs. Sol. Energy 2019, 190, 139-146. [CrossRef]

7. Lamnatou, C.; Chemisana, D. A critical analysis of factors affecting photovoltaic-green roof performance. Renew. Sustain. Energy Rev. 2015, 43, 264-280. [CrossRef]

8. Korjenic, A.; Tudiwer, D.; Penaranda Moren, M.S.; Hollands, J.; Salonen, T.; Mitterböck, M.; Pitha, U.; Zluwa, I.; Stangl, R.; Kräftner, J.; et al. Hocheffiziente Fassaden- und Dachbegrünung mit Photovoltaik- Kombination. Optimale Lösung für die Energieeffizienz in gesamtökologischer Betrachtung; Federal Ministry Republic of Austria: Vienna, Austria, 2018 2019; Available online: https:// nachhaltigwirtschaften.at/de/sdz/projekte/gruenplusschule-ballungszentrum-hocheffiziente-fassaden-und-dachbegruenungmit-photovoltaik-kombination-optimale-loesung-fuer-die-energieeffizienz-in-gesamtoekologischer-betrachtung.php (accessed on 20 January 2021).

9. Osma-Pinto, G.; Ordóñez-Plata, G. Measuring factors influencing performance of rooftop PV panels in warm tropical climates. Sol. Energy 2019, 185, 112-123. [CrossRef]

10. Jahanfar, A.; Drake, J.; Sleep, B.; Margolis, L. Evaluating the shading effect of photovoltaic panels on green roof discharge reduction and plant growth. J. Hydrol. 2019, 568, 919-928. [CrossRef]

11. Belčáková, I.; Świąder, M.; Bartyna-Zielińska, M. The Green Infrastructure in Cities as A Tool for Climate Change Adaptation and Mitigation: Slovakian and Polish Experiences. Atmosphere 2019, 10, 552. [CrossRef]

12. Scharf, B.; Kraus, F. Green Roofs and Greenpass. Buildings 2019, 9, 205. [CrossRef] 
13. Wootton-Beard, P.C.; Xing, Y.; Prabhakaran, R.T.D.; Robson, P.; Bosch, M.; Thornton, J.M.; Ormondroyd, G.A.; Jones, P.; Donnison, I. Review: Improving the Impact of Plant Science on Urban Planning and Design. Buildings 2016, 6, 48. [CrossRef]

14. What is a Green Roof? 2020. Available online: https://www.nps.gov/tps/sustainability/new-technology/green-roofs/define. htm (accessed on 4 April 2020).

15. Cascone, S. Green Roof Design: State of the Art on Technology and Materials. Sustainability 2019, 11, 3020. [CrossRef]

16. Köhler, M.; Ansel, W. Handbuch Bauwerksbegrünung: Planung, Konstruktion; Müller: Köln, Germany, 2012.

17. Austrian Standards Institute. ÖNORM L 1131 Gartengestaltung und Landschaftsbau-Begrünung von Dächern und Decken auf Bauwerken; Wien, Austria, 2010; p. 59.

18. Snodgrass, E.C.; McIntyre, L. The Green Roof Manual: A Professional Guide to Design, Installation, and Maintenance; Timber Press: London, UK; Portland, OR, USA, 2010.

19. Wong, N.; Cheong, D.; Yan, H.; Soh, J.; Ong, C.; Sia, A. The effects of rooftop garden on energy consumption of a commercial building in Singapore. Energy Build. 2003, 35, 353-364. [CrossRef]

20. Castleton, H.; Stovin, V.; Beck, S.B.; Davison, B. Green roofs; building energy savings and the potential for retrofit. Energy Build. 2010, 42, 1582-1591. [CrossRef]

21. Jaffal, I.; Ouldboukhitine, S.-E.; Belarbi, R. A comprehensive study of the impact of green roofs on building energy performance. Renew. Energy 2012, 43, 157-164. [CrossRef]

22. Medl, A.; Stangl, R.; Florineth, F. Vertical greening systems-A review on recent technologies and research advancement. Build. Environ. 2017, 125, 239. [CrossRef]

23. Bustami, R.A.; Belusko, M.; Ward, J.; Beecham, S. Vertical greenery systems: A systematic review of research trends. Build. Environ. 2018, 146, 226-237. [CrossRef]

24. Riley, B. The state of the art of living walls: Lessons learned. Build. Environ. 2017, 114, 219-232. [CrossRef]

25. Ottelé, M.; Perini, K.; Fraaij, A.; Haas, E.; Raiteri, R. Comparative life cycle analysis for green façades and living wall systems. Energy Build. 2011, 43, 3419-3429. [CrossRef]

26. Medl, A.; Florineth, F.; Kikuta, S.B.; Mayr, S. Irrigation of 'Green walls' is necessary to avoid drought stress of grass vegetation (Phleum pratense L.). Ecol. Eng. 2018, 113, 21-26. [CrossRef]

27. Tudiwer, D.; Teichmann, F.; Korjenic, A. Thermal bridges of living wall systems. Energy Build. 2019, 205, 109522. [CrossRef]

28. Kalogirou, S.A. Solar Energy Engineering; Academic Press: London, UK, 2013.

29. Celadyn, W.; Filipek, P. Investigation of the Effective Use of Photovoltaic Modules in Architecture. Buildings 2020, 10, 145. [CrossRef]

30. Design Trifft Funktion. Ertex Solar GmbH. Available online: https://www.ertex-solar.at/fuer-architekten/ (accessed on 26 September 2020).

31. Pearsall, N.M. Introduction to photovoltaic system performance. In The Performance of Photovoltaic (PV) Systems; Woodhead Publishing: Newcastle upon Tyne, UK, 2017.

32. Köhler, M.; Wiartalla, W.; Feige, R. Interaction between PV-systems and extensive green roofs. In Proceedings of the Fifth Greening Rooftops for Sustainable Communities Conference, Minneapolis, MN, USA, 29 April-1 May 2007.

33. Sattler, S.; Zluwa, I.; Österreicher, D. The "PV Rooftop Garden": Providing Recreational Green Roofs and Renewable Energy as a Multifunctional System within One Surface Area. Appl. Sci. 2020, 10, 1791. [CrossRef]

34. Lamnatou, C.; Chemisana, D. Photovoltaic-green roofs: A life cycle assessment approach with emphasis on warm months of Mediterranean climate. J. Clean. Prod. 2014, 72, 57-75. [CrossRef]

35. Schindler, B.Y.; Blank, L.; Levy, S.; Kadas, G.; Pearlmutter, D.; Blaustein, L. Integration of photovoltaic panels and green roofs: Review and predictions of effects on electricity production and plant communities. Isr. J. Ecol. Evol. 2016, 62, 68-73. [CrossRef]

36. Planungshilfe Solarenergie und Dachbegrünung. 2013. Available online: https://www.zinco.de/sites/default/files/2016-02/ Solarenergie_Dachbegruenung.pdf (accessed on 23 September 2020).

37. Solar Green Roof. Available online: https://www.optigreen.co.uk/system-solutions/solar-green-roof/system-build-up/ (accessed on 23 October 2020).

38. Pfoser, N. Photovoltaik und Gebäudebegrünung-Lösungen und Vorteile. Neue Landsch. 2019, 11, 44-45.

39. Pfoser, N. Gebäude, Begrünung, Energie: Potenziale und Wechselwirkungen. 1. Ausg. ed. FLL-Schriftenreihe Forschungsvorhaben: 2014, 1; FLL: Bonn, Germany, 2014.

40. Baumann, T.; Schär, D.; Carigiet, F.; Dreisiebner, A.; Baumgartner, F. Performance Analysis of PV Green Roof Systems. In Proceedings of the 23nd European Photovoltaic Solar Energy Conference and Exhibition, Munich, Germany, 30 May-3 June 2016.

41. UFA-Kräuter Solardach CH. Available online: https://www.ufasamen.ch/files/ufa-product-document/Kraeuter-Solardach-CH. pdf (accessed on 27 January 2021).

42. Ogaili, H. Measuring the Effect of Vegetated Roofs on the Performance of Photovoltaic Panels in Combined Systems. Master's Thesis, Portland State University, Portland, OR, USA, 2015.

43. Ogaili, H.; Sailor, D.J. Measuring the Effect of Vegetated Roofs on the Performance of Photovoltaic Panels in a Combined System. J. Sol. Energy Eng. 2016, 138, 061009. [CrossRef]

44. Schindler, B.Y.; Blaustein, L.; Lotan, R.; Shalom, H.; Kadas, G.J.; Seifan, M. Green roof and photovoltaic panel integration: Effects on plant and arthropod diversity and electricity production. J. Environ. Manag. 2018, 225, 288-299. [CrossRef] [PubMed] 
45. Moren, M.S.P.; Korjenic, A. Green buffer space influences on the temperature of photovoltaic modules: Multifunctional system: Building greening and photovoltaic. Energy Build. 2017, 146, 364-382. [CrossRef]

46. Penaranda Moren, M.S.; Korjenic, A. Hotter and colder-How Do Photovoltaics and Greening Impact Exterior Facade Temperatures: The synergies of a Multifunctional System. Energy Build. 2017, 147, 123-141. [CrossRef]

47. Stria, F. Pflanzenentwicklung in Gebäudebegrünungssystemen bei Kombination mit Photovoltaik: Am Standort GRG7 in Wien. Master's Thesis, University of Natural Resources and Life Sciences, Vienna, Austria, 2019.

48. Moren, M.S.P.; Korjenic, A. Untersuchungen zum ganzjährigen Wärmeschutz an Varianten eines kombinierten Dachaufbaus mit Photovoltaik und Begrünung. Bauphysik 2018, 40, 131-142. [CrossRef]

49. Nusser, C. Die Etablierung Pannonischer Vegetation auf Extensiven Dachbegrünungen. Master's Thesis, University of Natural Resources and Life Sciences, Vienna, Austria, 2019.

50. Wiartalla, W.; Zluwa, I.; (University of Natural Resources and Life Sciences, Vienna, Austria). Personal communication, 2020.

51. Bousselot, J.; Slabe, T.; Klett, J.; Koski, R. Environmental Protection Agency Photovoltaic Array Influences the Growth of Green Roof Plants. J. Living Arch. 2017, 4, 9-18. [CrossRef]

52. Utzer, K.; König, J. Dachgärten in Verbindung mit Photovoltaik: Untersuchung unterschiedlicher Photovoltaikmodule über einem Dachgarten. Master's Thesis, University of Natural Resources and Life Sciences, Vienna, Austria, 2014.

53. Kremer, A. Pflanzen unter Lichtdurchlässigen Photovoltaikmodulen: Untersuchung des Einflusses Unterschiedlicher Beschattungen Durch Lichtdurchlässige Photovoltaikmodule auf Indikatorpflanzen. Master's Thesis, University of Natural Resources and Life Sciences, Vienna, Austria, 2015.

54. Buchart, A. Gemüse am Dach: Entwicklung von Gemüsepflanzen und Kräuterpflanzen im Photovoltaik-Dachgarten. Master's Thesis, University of Natural Resources and Life Sciences, Vienna, Austria, 2018.

55. Macher, M. Intensive Dachbegrünung in Kombination mit Photovoltaik. Untersuchung des Einflusses von lichtdurchlässigen Photovoltaikmodulen auf mehrjährige Pflanzen am Beispiel PV-Dachgarten BOKU. Master's Thesis, University of Natural Resources and Life Sciences, Vienna, Austria, 2016.

56. Weixelbaumer, V.; Zluwa, I.; Weihs, P.P. Roof shelter living environment: An experimental study about increasing thermal comfort on a rooftop terrace by combining photovoltaic energy production and greenroofs. In E-Nova; Leykam: Pinkafeld, Austria, 2018

57. Weixelbaumer, V. Mikroklimatische Verhältnisse im Photovoltaik-Dachgärten: Aufenthaltsqualität in einem Dachgarten mit Überdachung aus lichtdurchlässigen Photovoltaikmodulen. Master's Thesis, University of Natural Resources and Life Sciences, Vienna, Austria, 2015.

58. Zluwa, I.; University of Natural Resources and Life Sciences, Vienna, Austria. Unpublished work. 2018.

59. Becker, G.; Leitner, B.; Stelzenhammer, O.; Absam, Austria. Report about the Energy Output in the PV-Roofgarden from 2017-2020. Unpublished work. 2020.

60. Brenneisen, S. Naturschutz auf Dachbegrünungen in Verbindung mit Solaranlagen; Baudepartement des Kantons Basel-Stadt Amt für Umwelt und Energie Stadtgärtnerei und Friedhöfe: Basel, Switzerland, 2014.

61. Shafique, M.; Luo, X.; Zuo, J. Photovoltaic-green roofs: A review of benefits, limitations, and trends. Sol. Energy 2020, $202,485-497$. [CrossRef]

62. Pearlmutter, D.; Theochari, D.; Nehls, T.; Pinho, P.; Piro, P.; Korolova, A.; Papaefthimiou, S.; Mateo, M.C.G.; Calheiros, C.; Zluwa, I. Enhancing the circular economy with nature-based solutions in the built urban environment: Green building materials, systems and sites. Blue-Green Syst. 2019, 2, 46-72. [CrossRef] 